Check for updates

Cite this: RSC Adv., 2018, 8, 1666

\title{
Novel spirocyclic tranylcypromine derivatives as lysine-specific demethylase 1 (LSD1) inhibitors $\uparrow$
}

Received 6th December 2017

Accepted 21st December 2017

DOI: $10.1039 / c 7 r a 13097 j$

rsc.li/rsc-advances

\author{
Ying Shi, $\dot{t}^{\mathrm{a}}$ Yan-Ran Wu, $\dot{t}^{\mathrm{a}}$ Ming-Bo Su, $\dot{t}^{\mathrm{b}}$ Dong-Hao Shen, ${ }^{\mathrm{a}}$ Hendra Gunosewoyo, ${ }^{\mathrm{c}}$ \\ Fan Yang, ${ }^{a}$ Jia Li, ${ }^{b}$ Jie Tang, ${ }^{d}$ Yu-Bo Zhou ${ }^{* b}$ and Li-Fang Yu (D) *a
}

Herein we describe the design, synthesis, and biological evaluation of a novel series of tranylcyprominebased LSD1 inhibitors via conformational restriction using spiro ring systems. A simple, direct spirocyclic analog of tranylcypromine (compounds $8 \mathrm{a}$ and $8 \mathrm{~b}$ ) was shown to be a 28 - to 129 -fold more potent inhibitor of LSD1 enzyme compared to tranylcypromine. Further incorporation of various substituted benzyl groups to the amino group resulted in a suite of $2^{\prime}, 3^{\prime}$-dihydrospiro[cyclopropane-1,1'-inden]-2amines that are potent LSD1 inhibitors with excellent selectivity profiles (e.g. 14a, 15b, 16a, 19a and 20b) against closely related enzymes such as MAO-A, MAO-B, and LSD2.

\section{Introduction}

Epigenetic modifications of DNA or histone tails, such as methylation and acetylation, provide regulatory mechanisms to influence gene expression. This dynamic process allows for the chromatin uncoiling or compaction, thereby altering the ability of the transcription machineries to access the DNA. Lysine-specific demethylase 1 (LSD1) is now recognized as the first true histone demethylase, originally discovered by the group of Shi Yang in 2004. ${ }^{1}$ LSD1 belongs to the flavin adenine dinucleotide (FAD)dependent amine oxidase superfamily and specifically demethylates mono- and dimethylated histone H3 lysine 4 (H3K4me and H3K4me2). ${ }^{1,2}$ The catalytic cycle is thought to involve the methylated lysine being firstly oxidized by FAD co-factor to form an imine intermediate, followed by hydrolysis to generate formaldehyde and the demethylated lysine. $\mathrm{FADH}_{2}$, the reduced product of FAD, is then oxidized by $\mathrm{O}_{2}$ to form FAD and $\mathrm{H}_{2} \mathrm{O}_{2}$. LSD1 is often present in transcriptional co-repressor complexes such as RE1-silencing transcriptional factor corepressor 1 (CoREST),

\footnotetext{
${ }^{a}$ Shanghai Engineering Research Center of Molecular Therapeutics and New Drug Development, School of Chemistry and Molecular Engineering, East China Normal University, 3663 North Zhongshan Road, Shanghai 200062, China. E-mail: Ifyu@ sat.ecnu.edu.cn; Tel: +86-021-622-31385

${ }^{b}$ CAS Key Laboratory of Receptor Research, National Center for Drug Screening, Shanghai Institute of Materia Medica, Chinese Academy of Sciences, 189 Guo Shou Jing Road, Shanghai 201203, China. E-mail: ybzhou@simm.ac.cn; Tel: +86-21-50801313

'School of Pharmacy, Faculty of Health Sciences, Curtin University, Bentley, Perth, WA 6102, Australia

${ }^{d}$ Shanghai Key Laboratory of Green Chemistry and Chemical Process, School of Chemistry and Molecular Engineering, East China Normal University, 3663 North Zhongshan Road, Shanghai 200062, China

$\dagger$ Electronic supplementary information (ESI) available: Spectrum of the corresponding compounds. See DOI: 10.1039/c7ra13097j

\$ These authors contributed equally.
}

which can stabilize and recruit LSD1 after binding to chromatin. ${ }^{3}$ Alteration of the LSD1 substrate specificity occurs upon association with the androgen receptor, namely from H3K4 to H3K9. ${ }^{4}$ LSD1 is also known for its ability to demethylate non-histone proteins, such as p53, thus inhibiting the apoptosis process mediated by $553 .^{5}$ In addition to LSD1, the LSD family has a homologue known as LSD2 which was first indentified in 2009. ${ }^{6,7}$ Both homologues contain the N-terminal SWIRM (Swi3p, Rsc8p and Moira) domain and the C-terminal amine oxidase domain. ${ }^{8}$ However, while LSD1 contains the Tower domain which forms a binding site with CoREST, the LSD2 contains a CW-type zinc finger domain with unknown function. ${ }^{6}$

There are numerous studies reporting that LSD1 is upregulated in various tumor tissue cells and tissues including retinoblastoma, ${ }^{\mathbf{C}}$ non-small cell lung cancer, ${ }^{\mathbf{1 0}}$ prostate cancer, ${ }^{\mathbf{1 1}}$ breast cancer, ${ }^{12,13}$ and colon cancer. ${ }^{14}$ LSD1 is also overexpressed in MLL-rearranged leukemia as a key regulator to promote the oncogenic potential of MLL-AF9 leukemia stem cell. ${ }^{15}$ MLL gene translocation is a major biomarker in acute leukemia which is typically associated with a poor prognosis. The results of RNAi-mediated knockdown or pharmacological inhibition of LSD1 seem to suggest that this enzyme induces reexpression of epigenetically silenced tumor suppressor genes and regulates p53 transcriptional activity or down-regulation of several leukemic-related genes. ${ }^{15-17}$ Overall, LSD1 represents a promising target for the treatment of leukemia as well as other solid tumors.

LSD1 exhibits homology with monoamine oxidases (MAOs) A and $\mathrm{B}$ with $17.6 \%$ identity. ${ }^{18}$ Classic MAO inhibitors such as trans-phenylcyclopropylamine (1, tPCPA), phenelzine (2), and pargyline (3) were found to show LSD1 inhibitory activity by forming covalent adduct with FAD (Fig. 1). The $(1 R, 2 S)$-isomer of 1 obtained by chiral resolution of tPCPA reacts with FAD in the active site to produce $N$-(5) adduct A, while the $(1 S, 2 R)$ - 
<smiles>NC1CC1c1ccccc1</smiles><smiles>NNCCc1ccccc1</smiles><smiles>C#CCN(C)Cc1ccccc1</smiles><smiles>COc1ncccc1CN[C@@H]1C[C@H]1c1ccccc1</smiles>

4

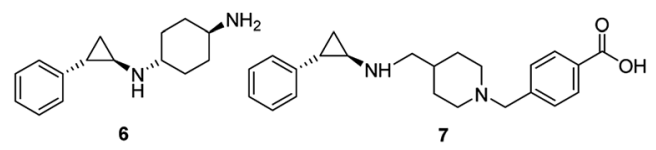

Fig. 1 Structures of irreversible LSD1 inhibitors.

isomer generates $N$-(5) adduct B (Fig. 2) ${ }^{18,19}$ A number of tPCPAcontaining inhibitors were developed with the aim to improve the potency at LSD1 as well as the selectivity over MAOs. The catalytic site for LSD1 is larger compared to MAOs, ${ }^{20}$ with substitutions at the phenyl ring and amino nitrogen atom generally increasing the LSD1 inhibitory activity. Compound $\mathbf{4}$ is a potent LSD1 inhibitor with an $\mathrm{IC}_{50}$ value of $98 \mathrm{nM}$ that has been demonstrated to inhibit colony forming capacity of MLL-AF9 leukemia cells. ${ }^{15}$ Compound 5 was reported to be a brain-permeable LSD1 inhibitor that can block memory consolidation in a mouse model. ${ }^{21}$ Other classes of reversible LSD1 inhibitors have also been reported, including peptides, polyamine analogues, pyrimidinethioureas, 3-(piperidin-4-ylmethoxy)pyridine and 3,5-diamino1,2,4-triazoles. ${ }^{22-27} N 1$-[(1R, 2S)-2-phenylcyclopropyl]cyclohexane1,4-diamine dihydrochlorideORY-1001 (6, ORY1001, RG6016, Oryzon Genomics) is an irreversible LSD1 inhibitor that was granted an orphan drug status for the treatment of acute myeloid leukemia (AML) in phase IIA clinical trial. ${ }^{28}$ GlaxoSmithKline developed a potent LSD1 inhibitor, compound 7 (GSK2879552), which is currently in the phase I trials for treatment of relapsed/ refractory small cell lung cancer and AML. More recently, Oryzon Genomics announced tPCPA analogue ORY2001, a dual LSD1/ MAO-B inhibitor, that was advanced in phase I studies for Alzheimer's disease in 2016. Other compounds currently in phase I/ II clinical trials for oncology include INCB059872, IMG-7289 and CC-90011. ${ }^{29}$

Although there are numerous medicinal chemistry campaigns on tranylcypromine-related analogues, ${ }^{30}$ thus far
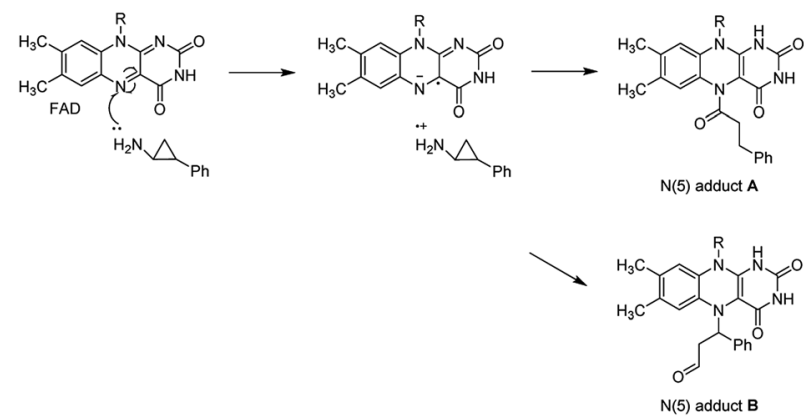

Fig. 2 Proposed mechanism of inactivation of LSD1 by tPCPA.
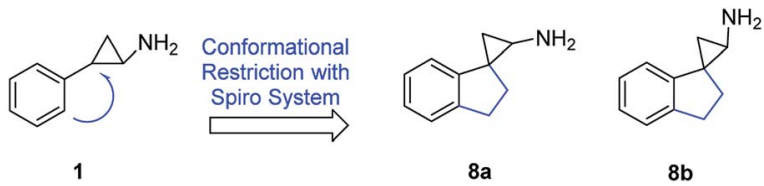

Fig. 3 Conformationally constrained compounds $8 \mathrm{a}$ and $8 \mathrm{~b}$.

there has been a limited report on the incorporation of spirocycle into the system. ${ }^{31,32}$ Spiro containing system has been increasingly utilized in medicinal chemistry as it introduces not only diverse orientation but also structural novelty. ${ }^{33}$ Within this context, the spirocycle constraint may influence the potency and selectivity for LSD1 inhibition over other homologous enzymes, such as LSD2, MAO-A, and MAO-B. In the present study, we report a series of $2^{\prime}, 3^{\prime}$-dihydrospiro[cyclopropane-1,1'inden]-2-amine analogues and their potencies at inhibiting LSD1 and related enzymes (Fig. 3).

\section{Results and discussion}

Compounds $\mathbf{8 a}$ and $\mathbf{8 b}$ were first synthesized as outlined in Scheme 1, starting from the commercially available 2,3-dihydro$1 H$-inden-1-one (9). Terminal olefin 10 was prepared via Wittig reaction with methyltriphenylphosphonium bromide. Cyclopropanation with ethyl diazoacetate catalyzed by rhodium(II) acetate dimer resulted in the esters 11a and 11b. Following basic hydrolysis, the corresponding carboxylic acids were in turn converted to the carbamates 12a and 12b via Curtius rearrangement using diphenylphosphoryl azide (DPPA), triethylamine and refluxing in anhydrous tert-butanol. The resultant enantiomers $\mathbf{1 2 a}$ and $\mathbf{1 2 b}$ were readily separated by flash chromatography and the stereochemical assignments were based collectively on their $1 H, 1 H$ COSY and Nuclear Overhauser Effect (NOE) NMR spectra (ESI Table 1†). Briefly, for the aromatic ring of compound $\mathbf{8 a}$, the $\mathrm{H}-5^{\prime}$ proton $(\delta 7.18-7.12)$ coupled with $\mathrm{H}-4^{\prime}(\delta 7.22)$ and $\mathrm{H}-6^{\prime}\left(\delta\right.$ 7.18-7.12). Similarly, $\mathrm{H}-6^{\prime}$ proton $(\delta 7.18-7.12)$ coupled with $\mathrm{H}-5^{\prime}(\delta 7.18-7.12)$ and $\mathrm{H}-7^{\prime}(\delta$ 6.76). In the aliphatic region, $\mathrm{H}-3^{\prime}(\delta 3.14)$ coupled with $\mathrm{H}-2^{\prime}(\delta$ 2.35-2.20) and the $\mathrm{H}-2(\delta$ 2.88) with $\mathrm{H}-3(\delta$ 1.42, 1.29). For compound 8a, NOE correlations were observed between $\mathrm{H}-7^{\prime}$ and $\mathbf{H}-2$. For compound $\mathbf{8 b}$, in the aromatic region, the $\mathbf{H}-6^{\prime}$

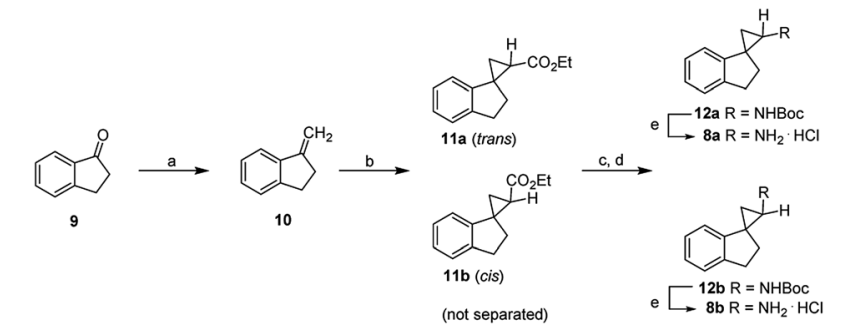

Scheme $1{ }^{a}$ Reagents and conditions: (a) methyltriphenylphosphonium bromide, ${ }^{t} \mathrm{BuOK}, \mathrm{THF}, \mathrm{rt}$; (b) $\mathrm{Rh}_{2}(\mathrm{OAc})_{4}$ (cat.), $\mathrm{N}_{2} \mathrm{CH}_{2} \mathrm{COOEt}, \mathrm{CH}_{2} \mathrm{Cl}_{2}, 45^{\circ} \mathrm{C}$; (c) $\mathrm{KOH}$, EtOH, $80{ }^{\circ} \mathrm{C}$; (d) i. diphenylphosphoryl azide (DPPA), $\mathrm{Et}_{3} \mathrm{~N}$, toluene, $0{ }^{\circ} \mathrm{C}-25^{\circ} \mathrm{C}$; ii. ${ }^{t} \mathrm{BuOH}$, reflux; (e) $4 \mathrm{M} \mathrm{HCl}$ in ethyl acetate, $r$. 
proton $\left(\delta\right.$ 7.26-7.21) coupled with $\mathrm{H}-5^{\prime}\left(\delta\right.$ 7.26-7.21) and $\mathrm{H}-\mathrm{7}^{\prime}(\delta$ $7.08-7.06)$. Similarly, the $\mathrm{H}-5^{\prime}$ proton $(\delta 7.26-7.21)$ coupled with $\mathrm{H}-4^{\prime}\left(\delta\right.$ 7.32) and $\mathrm{H}-6^{\prime}(\delta$ 7.26-7.21). In the aliphatic region, the $\mathrm{H}-3^{\prime}(\delta 3.18-3.10,2.97)$ coupled with $\mathrm{H}-2^{\prime}(\delta 2.38-2.30,1.97)$. The $\mathrm{H}-2$ proton $(\delta$ 2.88) coupled with $\mathrm{H}-3$ ( $\delta$ 1.51, 1.43). For compound $\mathbf{8 b}$, NOE correlations were seen for $\mathrm{H}-2$ and $\mathrm{H}-2^{\prime}$, and therefore supporting the stereochemical assignments of $\mathbf{8 a}$ as the trans-isomer and $\mathbf{8 b}$ as the cis-isomer. Lastly, deprotection of the Boc group in acidic conditions afforded final compounds $\mathbf{8 a}$ and $\mathbf{8 b}$ as hydrochloride salts.

Following their synthesis, compounds $\mathbf{8 a}$ and $\mathbf{8 b}$ were tested for their inhibitory activities against the purified LSD1 recombinant. As shown in Table 1 , compounds $\mathbf{8 a}$ and $\mathbf{8 b}$ drastically improved the inhibitory activity against LSD1 by 129and 28-fold compared to the control compound tPCPA (1), with the trans-isomer $\mathbf{8 a}$ being 5 -fold more potent than the cis-isomer 8b. Furthermore, both isomers exhibited very high selectivity of $>600$ - and $>120$ - fold against MAO-A, but only modest selectivity for MAO-B. The observed trend suggested that the conformational restriction imposed by the spirocycle was beneficial for the inhibitory activity against LSD1 and selectivity over MAO-A.

Encouraged by the preliminary in vitro results of the spirocycles $\mathbf{8 a}$ and $\mathbf{8 b}$, we further explored structural extensions on the amino group (13a-25a, 13b-25b). As outlined in Scheme 2, reductive amination of the amines $\mathbf{8 a}$ and $\mathbf{8 b}$ with various substituted benzaldehydes or pyridine aldehydes using $\mathrm{NaBH}_{4}$ gave the final products 13a-24a and 13b-25b. Alkylation of 8a or 8b with 2-chloro-1-morpholinoethan-1-one in the presence of sodium hydride in anhydrous dimethylformamide (DMF) provided the amides 25a and 25b. Their $\mathrm{IC}_{50}$ values for the

Table 1 In vitro inhibitory activities against LSD1, MAO-A, MAO-B, and LSD2 ${ }^{a}$
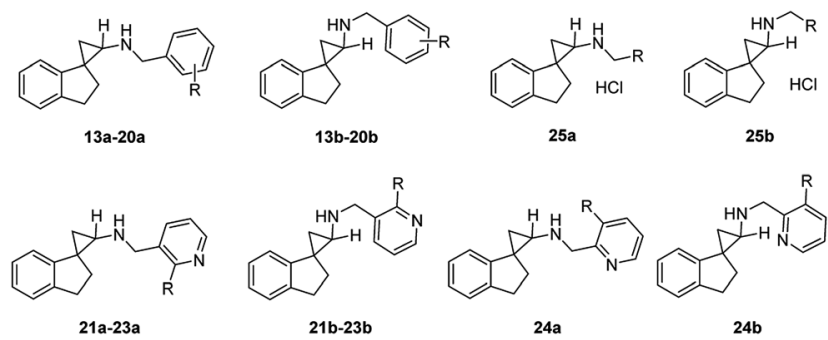

24b

\begin{tabular}{|c|c|c|c|c|}
\hline 1 & 22 & $11 \pm 4$ & $7.0 \pm 0.8$ & $\mathrm{NT}^{b}$ \\
\hline 6 & $0.014 \pm 0.003$ & $>100$ & $194 \pm 114$ & NT \\
\hline $8 \mathbf{b}$ & $0.78 \pm 0.05$ & $>100$ & $7.8 \pm 0.7$ & NT \\
\hline $13 a$ & $3.3 \pm 0.6$ & NT & NT & NT \\
\hline $13 b$ & $0.11 \pm 0.02$ & $0.13 \pm 0.01$ & $5.1 \pm 0.1$ & $2.0 \pm 0.2$ \\
\hline $15 a$ & $0.0070 \pm 0.0017$ & $4.8 \pm 0.5$ & $9.8 \pm 2.3$ & NT \\
\hline $15 b$ & $0.0011 \pm 0.0001$ & $2.5 \pm 0.1$ & $32 \pm 3$ & NT \\
\hline $16 a$ & $0.0095 \pm 0.0024$ & $3.7 \pm 0.8$ & $1.2 \pm 0.2$ & $6.8 \pm 1.0$ \\
\hline $16 b$ & $0.063 \pm 0.008$ & $0.39 \pm 0.19$ & $7.7 \pm 3.8$ & $4.7 \pm 0.8$ \\
\hline $17 a$ & $0.0066 \pm 0.0015$ & $0.92 \pm 0.18$ & $2.3 \pm 0.4$ & $0.80 \pm 0.27$ \\
\hline $17 \mathrm{~b}$ & $0.017 \pm 0.003$ & $0.12 \pm 0.01$ & $27 \pm 4$ & $1.7 \pm 0.5$ \\
\hline $20 \mathrm{a}$ & $0.025 \pm 0.007$ & $1.4 \pm 0.1$ & $20 \pm 1$ & $2.3 \pm 0.1$ \\
\hline $20 \mathrm{~b}$ & $0.0083 \pm 0.0019$ & $5.0 \pm 1.8$ & $7.0 \pm 0.7$ & $1.6 \pm 0.2$ \\
\hline $21 \mathrm{a}$ & $0.017 \pm 0.003$ & $10.8 \pm 1.1$ & $15 \pm 1$ & NT \\
\hline $21 b$ & $0.020 \pm 0.003$ & $6.0 \pm 1.1$ & $28 \pm 6$ & NT \\
\hline $22 a$ & $0.032 \pm 0.006$ & $>100$ & $47 \pm 5$ & NT \\
\hline $22 b$ & $0.010 \pm 0.005$ & $>100$ & $68 \pm 8$ & NT \\
\hline $23 a$ & $0.064 \pm 0.001$ & $9.7 \pm 1.5$ & $8.2 \pm 1.5$ & $13 \pm 3$ \\
\hline $23 b$ & $0.070 \pm 0.003$ & $9.8 \pm 0.8$ & $29 \pm 4$ & $8.7 \pm 0.8$ \\
\hline $24 a$ & $0.25 \pm 0.01$ & NT & NT & NT \\
\hline $24 b$ & $0.47 \pm 0.02$ & NT & NT & NT \\
\hline $25 \mathrm{a}$ & $1.4 \pm 0.1$ & NT & NT & NT \\
\hline $25 b$ & $22 \pm 4$ & NT & NT & NT \\
\hline
\end{tabular}

${ }^{a}$ See Experimental section. Data represent mean values \pm SEM of eight-point experiments each performed from three independent experiments. Positive controls: compound 1 and 6. ${ }^{b}$ NT: not tested. 

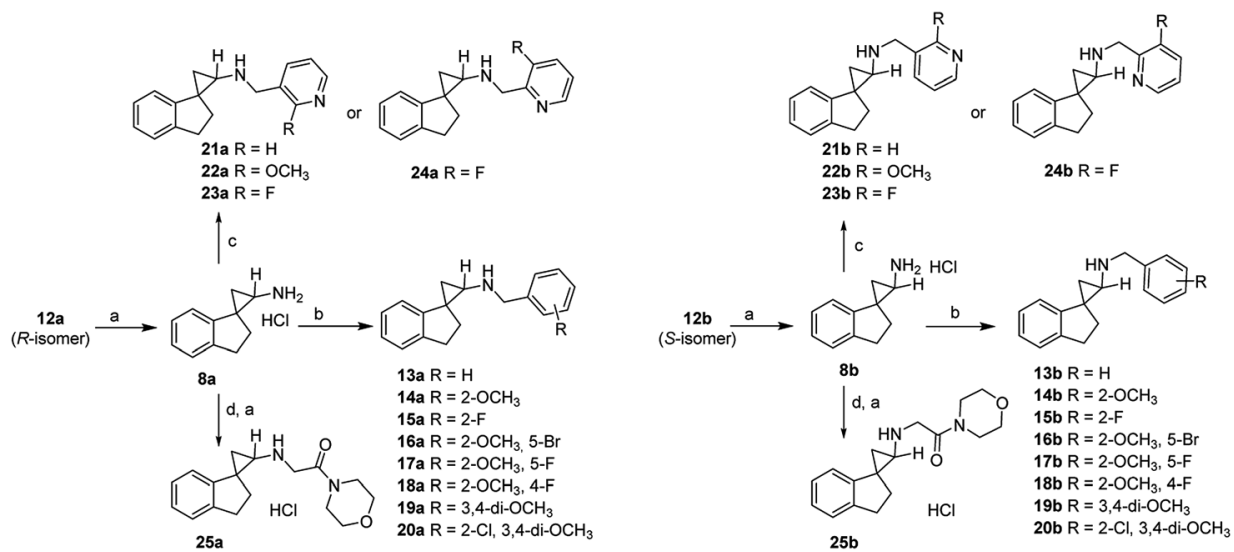

Scheme $2{ }^{a}$ Reagents and conditions: (a) $4 \mathrm{M} \mathrm{HCl}$ in ethyl acetate, $r$; (c) substituted pyridine aldehyde, $\mathrm{NaBH}_{4}, \mathrm{MeOH} \mathrm{rt}$; (b) substituted benzaldehyde, $\mathrm{NaBH}_{4}, \mathrm{MeOH}$, rt; (d) 2-chloro-1-morpholinoethan-1-one, $\mathrm{NaH}, \mathrm{DMF}, 0{ }^{\circ} \mathrm{C}$-rt.

inhibition of LSD1, MAO-A, MAO-B and LSD2 are summarized in Table 1.

A benzyl substitution on the amino group of 8 a resulted in a 19-fold decrease in the LSD1 inhibitory activity (13a vs. 8a: $\mathrm{IC}_{50}$ $=3.3 \mu \mathrm{M} v s .0 .17 \mu \mathrm{M})$, while the reverse trend was observed for 13b vs. $8 \mathbf{b}\left(\mathrm{IC}_{50}=0.11 \mu \mathrm{M}\right.$ vs. $\left.0.78 \mu \mathrm{M}\right)$. To our delight, all the other synthesized benzyl and pyridylmethyl derivatives demonstrated potent inhibitory activities at the LSD1 with $\mathrm{IC}_{50}$ values between $1.1 \mathrm{nM}$ and $0.47 \mu \mathrm{M}$ (14a-24a, 14b-24b). Generally, the trans-isomers are more potent LSD1 inhibitors compared to the corresponding cis-isomers, with the exceptions of 13a vs. 13b $\left(\mathrm{IC}_{50}=3.3 \mu \mathrm{M} v s .0 .11 \mu \mathrm{M}\right), 15 \mathrm{a} v s .15 \mathrm{~b}\left(\mathrm{IC}_{50}=7.0 \mathrm{nM} v s .1 .1 \mathrm{nM}\right)$, 20a vs. $20 \mathrm{~b}\left(\mathrm{IC}_{50}=25 \mathrm{nM}\right.$ vs. $\left.8.3 \mathrm{nM}\right)$, and $22 \mathrm{a}$ vs. $22 \mathrm{~b}\left(\mathrm{IC}_{50}=\right.$ $32 \mathrm{nM} v s .10 \mathrm{nM}$ ). In particular, a 2-methoxybenzyl (14a, 14b) or 2fluorobenzyl substituents $(\mathbf{1 5 a}, \mathbf{1 5 b})$ on the amino group enhanced the inhibitory potencies to single digit nanomolar levels, indicating that both electron donating and withdrawing groups are tolerated at the 2-position of the aromatic ring. Within the disubstituted benzyl analogues (16a-19a, 16b-19b), all the trans-isomers were found to be more potent inhibitors of LSD1 compared to their corresponding cis-isomers. Among the 2,5disubstituted benzyls analogues 16a-17a and $\mathbf{1 6 b - 1 7 b}$, while the trans-isomers are almost equipotent at LSD1, the additional 5fluoro substitution gave slightly more potent compounds than the 5-bromo substitution (17b vs. $\mathbf{1 6 b})$ for the cis-isomers, indicating potential steric issues at this region. Moving the fluoro substituent from the 5- to the 4-position of the benzyl group did not elicit significant changes in the $\mathrm{IC}_{50}$ values $(\mathbf{1 7 a}, \mathbf{1 7} \mathbf{b}$ vs. 18a, 18b). The 3,4-dimethoxy analogues $(19 a, 19 b)$ were almost as equipotent as the 2-methoxy analogue $(\mathbf{1 4 a}, \mathbf{1 4 b})$. For the trisubstituted benzyl analogue 20, the cis-isomer (20b) was found to be 3 -fold more potent than the trans-isomer (20a). Changing a benzyl to a 3-pyridylmethyl group (21a-23a, 21b-23b) resulted in essentially equipotent isomers, with the exception of the 2methoxy derivative, where the trans-isomer 22a $\left(\mathrm{IC}_{50}=32 \mathrm{nM}\right)$ was 3-fold less potent than the cis-isomer $22 \mathbf{b}\left(\mathrm{IC}_{50}=10 \mathrm{nM}\right)$. The unsubstituted 3-pyridylmethyl analogues 21a and $21 \mathbf{b}$ were found to be 10 -fold and 39 -fold more potent than $\mathbf{8 a}$ and $\mathbf{8 b}$, respectively. The 2-methoxy analogues $22 \mathbf{a}$ and $\mathbf{2 2 b}$ exhibited similar inhibitory activity against LSD1 compared with 21a and 21b. However, the 2-fluoro derivatives 23a and 23b were approximately 4 -fold less potent than the unsubstituted derivatives 21a and 21b $\left(\mathrm{IC}_{50}=64\right.$ and $\left.70 \mathrm{nM}\right)$. Keeping the fluoro group intact, a pyridyl walk from 3- to the 2-position (24a, 24b vs. 23a, 23b) resulted in at least a 4 -fold reduction in their LSD1 inhibitory potencies. Swapping the aromatic group to an aliphatic morpholinecarbonyl $(25 a, 25 b)$ showed a further significant reduction in the LSD1 inhibitory activities, with $\mathrm{IC}_{50}$ values of 1.4 and $22 \mu \mathrm{M}$, respectively. In terms of selectivity for LSD1 inhibition over other related enzymes LSD2, MAO-A and MAO-B, all of the synthesized target compounds were the most potent at inhibiting LSD1 with selectivity index varying between low (e.g. $\mathrm{IC}_{50}$ values of $\mathbf{1 3 b}$ and $\mathbf{1 8 b}$ for LSD1 vs. MAO-A) and excellent (e.g. $\mathrm{IC}_{50}$ values of $\mathbf{1 4 a}, \mathbf{1 5 b}$, 16a, 19a and 20b for LSD1 vs. MAO-A, MAO-B and LSD2).

The subsequent round of structural activity relationship (SAR) investigations involved structural extensions on the aromatic ring of the dihydroindene. As shown in Scheme 3, the commercially available 5-bromo-2,3-dihydro- $1 \mathrm{H}$-inden-1-one (26) were used as the starting material and subjected to the conditions

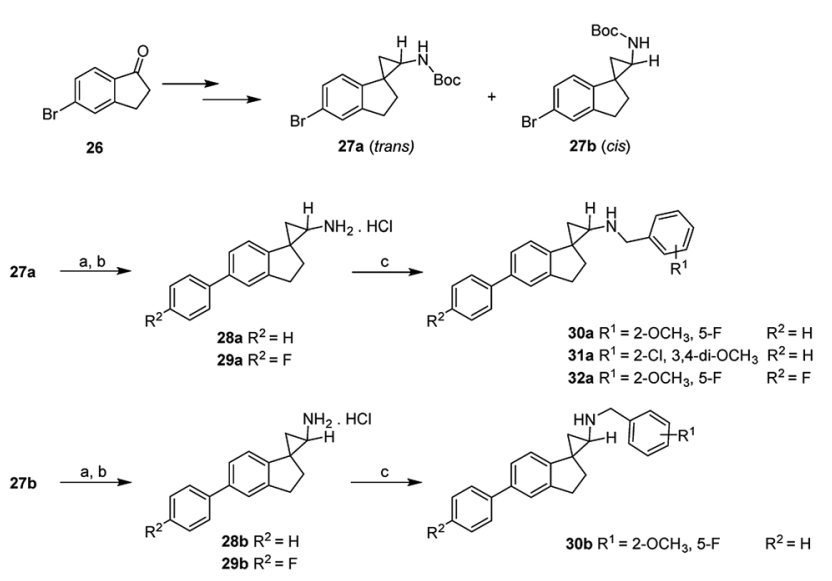

Scheme $3{ }^{a}$ Reagents and conditions: (a) $\mathrm{Pd}\left(\mathrm{PPh}_{3}\right)_{4}$ (cat.), boronic acid, $\mathrm{Na}_{2} \mathrm{CO}_{3}, \mathrm{DMF}, 80^{\circ} \mathrm{C}$; (b) $4 \mathrm{M} \mathrm{HCl}$ in EtOAc, rt; (c) substituted benzaldehyde, $\mathrm{NaBH}_{4}, \mathrm{MeOH}$, rt. 
Table 2 In vitro inhibitory activities of $28 a-32 a$ and $28 b-30 b$ against $\mathrm{LSD}^{a}$

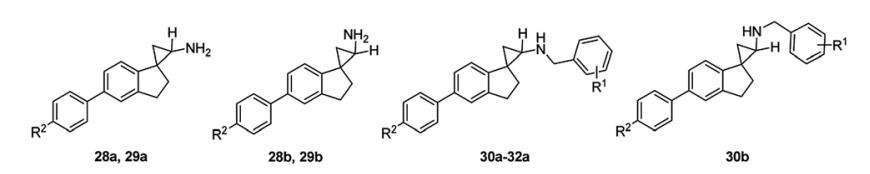

\begin{tabular}{llll} 
Compound & $R^{1}$ & $R^{2}$ & LSD1, IC $50(\mu \mathrm{M})$ \\
\hline $\mathbf{1}$ & - & - & 22 \\
$\mathbf{8 a}$ & - & - & $0.17 \pm 0.01$ \\
$\mathbf{8 b}$ & - & - & $0.78 \pm 0.05$ \\
$\mathbf{2 8 a}$ & - & $\mathrm{H}$ & $0.10 \pm 0.01$ \\
$\mathbf{2 8 b}$ & - & $\mathrm{H}$ & $2.7 \pm 0.2$ \\
29a & - & $\mathrm{F}$ & $0.30 \pm 0.01$ \\
29b & - & $\mathrm{F}$ & $6.0 \pm 0.8$ \\
30a & $2-\mathrm{OCH}_{3}, 5-\mathrm{F}$ & $\mathrm{H}$ & $1.7 \pm 0.1$ \\
30b & $2-\mathrm{OCH}_{3}, 5-\mathrm{F}$ & $\mathrm{H}$ & $4.4 \pm 0.3$ \\
31a & $2-\mathrm{Cl}_{3}, 4-\mathrm{di}-\mathrm{OCH}$ & $\mathrm{H}$ & $8.9 \pm 1.2$ \\
32a & $2-\mathrm{OCH}_{3}, 5-\mathrm{F}$ & $\mathrm{F}$ & $2.6 \pm 0.5$
\end{tabular}

${ }^{a}$ See Experimental Section. Data represent mean values \pm SEM of eightpoint experiments each performed from three independent experiments. Positive control: compound 1.

as previously outlined in Scheme 2. The isomers 27a and 27b were separated by flash chromatography and the relative stereochemistry assigned based on a combination of their COSY and NOESY studies. Suzuki coupling of 27a with aromatic boronic acid in the presence of $\mathrm{Pd}\left(\mathrm{PPh}_{3}\right)_{4}$ at $80{ }^{\circ} \mathrm{C}$ in degassed $1 \mathrm{M}$ $\mathrm{Na}_{2} \mathrm{CO}_{3}$ (aq)/DMF, followed by deprotection of the Boc group afforded the desired compounds 28a and 29a. Compounds $28 \mathbf{b}$ and 29b were synthesized following identical procedures with 27b as the starting material. The final compounds 30a-32a and 30b were readily accessed via reductive amination of the corresponding precursors with various substituted benzaldehydes and $\mathrm{NaBH}_{4}$ as the reducing agent. Their inhibitory activities at LSD1 and related enzymes are shown in Table 2.

As demonstrated in Table 2, an unsubstituted benzene ring extension at the aromatic group of the dihydroindene gave opposite effects depending on the stereochemistry of the cyclopropanamine. For the trans-isomers, a very slight increase in potency was observed (28a vs. 8a), whereas an opposite trend was seen for the cis-isomers (28b vs. 8b), with $28 \mathbf{b}$ having an $\mathrm{IC}_{50}$ value of $2.7 \mu \mathrm{M}$ against LSD1. A 4-fluoro substitution on the newly added benzene ring resulted in approximately 3 -fold reduction in the LSD1 inhibitory potencies (29a, 29b vs. 28a, 28b). The remaining synthesized compounds 30a, 30b, 31a and 32a all showed $\mathrm{IC}_{50}$ values in the single digit micromolar range, indicating a potentially undesired steric effect at this region. As the most potent LSD1 inhibitor arising from this biphenyl series, compound 28a was further tested against other enzymes MAO-A, MAO-B and LSD2, with $\mathrm{IC}_{50}$ values of $0.46 \mu \mathrm{M}, 0.17 \mu \mathrm{M}$ and $94 \mu \mathrm{M}$, respectively.

\section{Conclusion}

In summary, a novel series of $2^{\prime}, 3^{\prime}$-dihydrospiro[cyclopropane1,1'-inden]-2-amine analogues as potent LSD1 inhibitors have been developed. In line with the conformational restriction conferred by the spirocycle to the tranylcypromine system, compounds $\mathbf{8 a}$ and $\mathbf{8 b}$ displayed significant improvements in their LSD1 inhibitory potencies and high selectivities for MAOA. In order to further explore the SAR, structural modifications on the amino group and the benzene ring of the dihydroindene were found to give more potent compounds. Specifically, the addition of substituted benzyl moieties to the amino group (13a-25a, 13b-25b) showed single digit nanomolar potencies against LSD1 and excellent selectivity profiles against the homologous MAO enzymes and LSD2. While most of the transisomers were generally found to be more potent than the corresponding cis-isomers, there were some exceptions in the SAR data. The additional aromatic moiety at the benzene ring of the dihydroindene (28a-32a, 28b-30b) resulted in a significant drop of the LSD1 inhibitory potencies, indicating an unfavorable steric clash at this region. Overall, these studies warrant the further development of spirocyclic tranylcypromine derivatives as potent and selective LSD1 inhibitors.

\section{Experimental}

\section{Chemistry}

Starting materials, reagents, and solvents were purchased from commercial suppliers and used without further purification, unless otherwise stated. Anhydrous tetrahedrofuran (THF) and $\mathrm{CH}_{2} \mathrm{Cl}_{2}$ were obtained by distillation over sodium wire or $\mathrm{CaH}_{2}$, respectively. All non-aqueous reactions were run under a nitrogen atmosphere with exclusion of moisture from reagents, and all reaction vessels were oven-dried. The progress of reactions was monitored by TLC on $\mathrm{SiO}_{2}$. Spots were visualized by their quenching of the fluorescence of an indicator admixed to the $\mathrm{SiO}_{2}$ layer, or by dipping into phosphomolybdic acid ethanol solution followed by heating. $\mathrm{SiO}_{2}$ for flash chromatography was of 200-300 mesh particle size, and an EtOAc/ PE mixture or gradient was used unless stated otherwise. ${ }^{1} \mathrm{H}$ NMR spectra were recorded at a spectrometer frequency of 400 $\mathrm{MHz},{ }^{13} \mathrm{C}$ NMR spectra at $101 \mathrm{MHz}$. Chemical shifts are reported in $\delta$ (ppm) using the $\delta 0$ signal of tetramethylsilane (TMS) as internal standard. High resolution mass spectra were performed using a Bruker ESI-TOF high-resolution mass spectrometer and Waters Micromass Q-TOF micro Synapt high definition mass spectrometer.

1-Methylene-2,3-dihydro- $1 \mathrm{H}$-indene (10). To a solution of 2,3-dihydro- $1 H$-inden-1-one (9, $4.00 \mathrm{~g}, 30.3 \mathrm{mmol})$ and methyltriphenylphosphonium bromide $(12.97 \mathrm{~g}, 36.32 \mathrm{mmol})$ in THF $(20 \mathrm{~mL})$ was added potassium tert-butoxide $(4.08 \mathrm{~g}, 36.32 \mathrm{mmol})$ in THF $(20 \mathrm{~mL})$ via an addition funnel over $0.5 \mathrm{~h}$. The resulting mixture was stirred at room temperature for $16 \mathrm{~h}$. The solvent was removed under vacuum and the residue was purified by flash chromatography on silica gel, eluting with PE/EtOAc $(100: 1)$ to provide the title compound 10. Colorless oil; yield $87 \% .{ }^{1} \mathrm{H}$ NMR (400 MHz, $\mathrm{CDCl}_{3}$ ) $\delta$ 7.49-7.47 (m, 1H), 7.25-7.23 $(\mathrm{m}, 1 \mathrm{H}), 7.21-7.16(\mathrm{~m}, 2 \mathrm{H}), 5.45-5.43(\mathrm{~m}, 1 \mathrm{H}), 5.02-5.01(\mathrm{~m}$, $1 \mathrm{H}), 2.96$ (t, $J=7.0 \mathrm{~Hz}, 2 \mathrm{H}), 2.80-2.77(\mathrm{~m}, 2 \mathrm{H})$.

Ethyl 2' $\quad 2^{\prime}, 3^{\prime}$-dihydrospiro[cyclopropane-1,1'-indene]-2carboxylate (11a and 11b). To a solution of 10 (3.42 g, 26.27 
$\mathrm{mmol}$ ) and rhodium(II) acetate dimer (115 $\mathrm{mg}, 0.26 \mathrm{mmol}$ ) in refluxing $\mathrm{CH}_{2} \mathrm{Cl}_{2}(5 \mathrm{~mL})$ was added ethyl diazoacetate $(8.98 \mathrm{~g}$, $78.81 \mathrm{mmol})$ in $\mathrm{CH}_{2} \mathrm{Cl}_{2}(2 \mathrm{~mL})$ via syringe pump over $1 \mathrm{~h}$. After refluxing for $3 \mathrm{~h}$ the resulting mixture was stirred at room temperature overnight. The solvent was removed under vacuum and the residue was purified by flash chromatography on silica gel, eluting with PE/EtOAc $(100: 1)$ to provide the title compounds 11a and 11b as a mixture. Colorless oil; total yield $59 \%$. The diastereoisomers $11 \mathrm{a}$ and $\mathbf{1 1 b}$ were not isolated and used directly in the next reaction.

tert-Butyl ((2R)-2', $3^{\prime}$-dihydrospiro[cyclopropane-1,1'-inden]2-yl)carbamate (12a) and tert-butyl ((2S)-2', $3^{\prime}$-dihydrospiro [cyclopropane-1,1'-inden]-2-yl)carbamate (12b). To a stirred solution of 11a and $11 \mathrm{~b}(3.35 \mathrm{~g}, 15.49 \mathrm{mmol})$ in EtOH $(10 \mathrm{~mL})$ was added $\mathrm{KOH}(2.61 \mathrm{~g}, 46.47 \mathrm{mmol})$. After refluxing for $3 \mathrm{~h}$, the reaction was cooled to $\mathrm{rt}$. EtOAc $(20 \mathrm{~mL})$ was added to the reaction mixture, followed by extraction with $\mathrm{H}_{2} \mathrm{O}(3 \times 30 \mathrm{~mL})$. A $10 \%$ aqueous hydrochloric acid solution was added to the combined aqueous layers until $\mathrm{pH}$ value dropped to 5-6, which was then extracted with EtOAc $(3 \times 30 \mathrm{~mL})$. The combined organic layers were washed with brine $(1 \times 30 \mathrm{~mL})$, dried over $\mathrm{Na}_{2} \mathrm{SO}_{4}$, filtered and concentrated in vacuo to afford an oil. This residue was then reacted with triethylamine $(6.4 \mathrm{~mL}, 46.47$ $\mathrm{mmol})$ and diphenylphosphorylazide $(6.7 \mathrm{~mL}, 30.98 \mathrm{mmol})$ in anhydrous toluene $(20 \mathrm{~mL})$ at $0{ }^{\circ} \mathrm{C}$ while stirring under an argon atmosphere. The reaction mixture was warmed to $25^{\circ} \mathrm{C}$ over $4 \mathrm{~h}$, then washed with water $(3 \times 50 \mathrm{~mL})$, brine $(1 \times 30 \mathrm{~mL})$, dried over $\mathrm{Na}_{2} \mathrm{SO}_{4}$, filtered and concentrated in vacuo. The residual azide was dissolved in anhydrous tert-butanol $(100 \mathrm{~mL})$ while stirring and heated to reflux for $6 \mathrm{~h}$. After completion, the reaction was cooled to $25{ }^{\circ} \mathrm{C}$ and concentrated in vacuo to afford a brown oil. The oil was diluted with EtOAc $(50 \mathrm{~mL})$ and washed with saturated sodium bicarbonate $(1 \times 50 \mathrm{~mL})$, brine $(1 \times 30$ $\mathrm{mL}$ ), dried over $\mathrm{Na}_{2} \mathrm{SO}_{4}$, filtered and concentrated in vacuo. The crude carbamate was purified by flash chromatography in $\mathrm{PE} /$ EtOAc $(30: 1)$ to yield the pure product 12a (first elution) and 12b (second elution). 12a: white solid, yield $27 \%$. ${ }^{1} \mathrm{H}$ NMR (400 $\left.\mathrm{MHz} \mathrm{CDCl}_{3}\right) \delta 7.18(\mathrm{~d}, J=4.0 \mathrm{~Hz}, 1 \mathrm{H}), 7.11-7.10(\mathrm{~m}, 2 \mathrm{H}), 6.65-$ $6.63(\mathrm{~m}, 1 \mathrm{H}), 4.78(\mathrm{~s}, 1 \mathrm{H}), 3.12-2.99(\mathrm{~m}, 2 \mathrm{H}), 2.75(\mathrm{~s}, 1 \mathrm{H}), 2.18-$ $2.02(\mathrm{~m}, 2 \mathrm{H}), 1.44-1.33(\mathrm{~m}, 9 \mathrm{H}), 1.26-0.90(\mathrm{~m}, 2 \mathrm{H}) .{ }^{13} \mathrm{C} \mathrm{NMR}$ $\left(100 \mathrm{MHz}, \mathrm{CDCl}_{3}\right) \delta 156.4,146.2,143.7,126.4,126.1,124.3$, 118.5, 79.5, 36.2, 32.9, 30.8, 28.9, 28.3, 21.4. 12b: white solid; yield $19 \% .{ }^{1} \mathrm{H}$ NMR (400 MHz, $\mathrm{CDCl}_{3}$ ) $\delta 7.24-7.20(\mathrm{~m}, 1 \mathrm{H}), 7.15-$ $7.09(\mathrm{~m}, 2 \mathrm{H}), 6.81(\mathrm{~s}, 1 \mathrm{H}), 4.86-4.67(\mathrm{~m}, 1 \mathrm{H}), 3.16-2.92(\mathrm{~m}, 2 \mathrm{H})$, $2.76(\mathrm{~s}, 1 \mathrm{H}), 2.28-1.90(\mathrm{~m}, 2 \mathrm{H}), 1.31-1.12(\mathrm{~m}, 11 \mathrm{H}) .{ }^{13} \mathrm{C}$ NMR $\left(101 \mathrm{MHz}, \mathrm{CDCl}_{3}\right) \delta 156.3,145.7,142.4,126.2,125.8,124.4$, 121.2, 79.2, 36.2, 35.1, 33.4, 30.8, 28.2, 19.6 .

(2R)-2', $3^{\prime}$-Dihydrospiro[cyclopropane-1,1'-inden]-2-amine hydrochloride (8a). A solution of $12 \mathrm{a}(300 \mathrm{mg}, 1.16 \mathrm{mmol}$ ) and $4 \mathrm{M}$ $\mathrm{HCl}$ in EtOAc $(5 \mathrm{~mL})$ was stirred at room temperature overnight. The precipitated solid was filtered, washed with diethyl ether and dried to afford $\mathbf{8 a}$ as hydrochloride salt. Yellow solid; yield 98\%. ${ }^{1} \mathrm{H}$ NMR (400 MHz, $\left.\mathrm{CD}_{3} \mathrm{OD}\right) \delta$ 7.23-7.21 (m, 1H), 7.18-7.12 $(\mathrm{m}, 2 \mathrm{H}), 6.77-6.75(\mathrm{~m}, 1 \mathrm{H}), 3.14(\mathrm{t}, J=7.6 \mathrm{~Hz}, 2 \mathrm{H}), 2.88(\mathrm{dd}, J=$ 8.0, 4.8 Hz, 1H), 2.34-2.20 (m, 2H), 1.44-1.27 (m, 2H). ${ }^{13} \mathrm{C}$ NMR (101 MHz, $\left.\mathrm{CD}_{3} \mathrm{OD}\right) \delta 145.4,144.8,128.2,128.0,125.5,120.0$,
35.3, 31.9, 31.5, 29.4, 19.9. HRMS (ESI): calcd for $\mathrm{C}_{11} \mathrm{H}_{14} \mathrm{~N}[\mathrm{M}+$ $\mathrm{H}]^{+}, 160.1121$; found 160.1114 .

(2S)-2', $3^{\prime}$-Dihydrospiro[cyclopropane-1,1'-inden]-2-amine hydrochloride (8b). This compound was synthesized from $\mathbf{1 2 b}$ according to the methodology described for 12a. Yellow solid; yield 94\%. ${ }^{1} \mathrm{H}$ NMR (400 MHz, $\left.\mathrm{CD}_{3} \mathrm{OD}\right) \delta 7.32-7.31(\mathrm{~m}, 1 \mathrm{H})$, 7.26-7.21 (m, 2H), 7.08-7.06 (m, 1H), 3.18-2.94 (m, 2H), 2.88 (dd, $J=7.6,4.8 \mathrm{~Hz}, 1 \mathrm{H}), 2.38-1.94(\mathrm{~m}, 2 \mathrm{H}), 1.52-1.41(\mathrm{~m}, 2 \mathrm{H})$. ${ }^{13} \mathrm{C}$ NMR $\left(101 \mathrm{MHz}, \mathrm{CD}_{3} \mathrm{OD}\right) \delta 147.5,140.4,128.7,127.7,126.3$, 121.9, 36.6, 35.0, 33.1, 31.5, 15.7. HRMS (ESI): calcd for $\mathrm{C}_{11} \mathrm{H}_{14} \mathrm{~N}$ $[\mathrm{M}+\mathrm{H}]^{+}, 160.1121$; found 160.1124 .

(2R)- $N$-Benzyl-2', $3^{\prime}$-dihydrospiro[cyclopropane-1,1'-inden]-2amine (13a). Triethylamine (39 $\mathrm{mg}, 0.39 \mathrm{mmol}$ ) was added to a solution of $8 \mathbf{a}(50 \mathrm{mg}, 0.26 \mathrm{mmol})$ in $\mathrm{MeOH}(2 \mathrm{~mL})$ at rt to produce the free amine. Then benzaldehyde $(28 \mathrm{mg}, 0.26$ mmol) was added and the mixture was stirred at rt for $0.5 \mathrm{~h}$. Molecular sieves type $4 \AA$ (300 mg) were added and the mixture was stirred for another $0.25 \mathrm{~h}$. Sodium borohydride $(15 \mathrm{mg}$, $0.39 \mathrm{mmol}$ ) was then added in a single portion. After overnight stirring, the mixture was then filtered and the solvent removed in vacuo to give the crude product which was partitioned between saturated $\mathrm{NaHCO}_{3}(20 \mathrm{~mL})$ and EtOAc $(20 \mathrm{~mL})$, followed by extraction with EtOAc $(3 \times 30 \mathrm{~mL})$. The organic phase was combined, dried over $\mathrm{Na}_{2} \mathrm{SO}_{4}$, filtered, and concentrated in vacuo. The crude product was purified by flash chromatography in PE/EtOAc $(15: 1)$ to yield the pure product 13a. Yellow oil; yield $42 \%$. ${ }^{1} \mathrm{H}$ NMR $\left(400 \mathrm{MHz}, \mathrm{CDCl}_{3}\right) \delta 7.32-7.28(\mathrm{~m}, 4 \mathrm{H}), 7.26-$ 7.23 (m, 1H), 7.20-7.17 (m, 1H), 7.12-7.08 (m, 2H), 6.64-6.60 $(\mathrm{m}, 1 \mathrm{H}), 3.86-3.78(\mathrm{~m}, 2 \mathrm{H}), 3.08-2.92(\mathrm{~m}, 2 \mathrm{H}), 2.42-2.34(\mathrm{~m}$, 2H), 2.17-2.09 (m, 1H), $1.90(\mathrm{~s}, 1 \mathrm{H}), 1.18-0.85(\mathrm{~m}, 2 \mathrm{H}) \cdot{ }^{13} \mathrm{C} \mathrm{NMR}$ $\left(101 \mathrm{MHz}, \mathrm{CDCl}_{3}\right) \delta 147.8,143.8,140.4,128.4,128.2,127.0$, 126.3, 125.7, 124.2, 118.4, 53.9, 44.8, 33.6, 30.9, 28.4, 22.0. HRMS (ESI): calcd for $\mathrm{C}_{18} \mathrm{H}_{20} \mathrm{~N}[\mathrm{M}+\mathrm{H}]^{+}, 250.1590$; found 250.1594 .

(2S)- $N$-Benzyl-2', $3^{\prime}$-dihydrospiro[cyclopropane-1,1'-inden]-2amine (13b). This compound was obtained from $\mathbf{8 b}$ and benzaldehyde according to the methodology described for 13a. Yellow oil; yield 39\%. ${ }^{1} \mathrm{H}$ NMR $\left(400 \mathrm{MHz}, \mathrm{CDCl}_{3}\right) \delta 7.27-7.23$ (m, 2H), 7.21-7.17 (m, 2H), 7.15-7.13 (m, 5H), 3.58-3.39 (m, $2 \mathrm{H}), 3.07-2.91(\mathrm{~m}, 2 \mathrm{H}), 2.44(\mathrm{dd}, J=7.0,4.6 \mathrm{~Hz}, 1 \mathrm{H}), 2.23-1.82$ (m, 2H), 1.08-1.01 (m, 2H). ${ }^{13} \mathrm{C}$ NMR (101 MHz, $\left.\mathrm{CDCl}_{3}\right) \delta 145.2$, $143.9,140.5$, 128.3, 128.2, 126.8, 125.7, 125.6, 124.0, 122.3, 53.5, 44.8, 35.5, 33.8, 30.8, 20.4. HRMS (ESI): calcd for $\mathrm{C}_{18} \mathrm{H}_{20} \mathrm{~N}$ $[\mathrm{M}+\mathrm{H}]^{+}, 250.1590$; found 250.1601 .

(2R)- $N$-(2-Methoxybenzyl)-2', $3^{\prime}$-dihydrospiro[cyclopropane-1, $1^{\prime}$ inden]-2-amine (14a). This compound was obtained from 8a and 2-methoxybenzaldehyde according to the methodology described for 13a. Yellow oil; yield 65\%. ${ }^{1} \mathrm{H}$ NMR (400 $\left.\mathrm{MHz}, \mathrm{CDCl}_{3}\right) \delta 7.23-$ $7.17(\mathrm{~m}, 3 \mathrm{H}), 7.11-7.05(\mathrm{~m}, 2 \mathrm{H}), 6.89-6.85(\mathrm{~m}, 1 \mathrm{H}), 6.82(\mathrm{~d}, J=$ 8.0 Hz, 1H), 6.60-6.56 (m, 1H), 3.88-3.74 (m, 5H), 3.07-2.93 (m, $2 \mathrm{H}), 2.43-2.36(\mathrm{~m}, 1 \mathrm{H}), 2.28(\mathrm{dd}, J=7.4,4.6 \mathrm{~Hz}, 1 \mathrm{H}), 2.15-2.07(\mathrm{~m}$, 1H), 2.03 (s, 1H), 1.15-0.85 (m, 2H). ${ }^{13} \mathrm{C}$ NMR (101 MHz, $\mathrm{CDCl}_{3}$ ) $\delta 157.6,148.0,143.8,129.9,128.4,128.2,126.2,125.6,124.1,120.3$, 118.4, 110.2, 55.1, 49.2, 44.7, 33.5, 30.9, 28.3, 22.0. HRMS (ESI): calcd for $\mathrm{C}_{19} \mathrm{H}_{22} \mathrm{NO}[\mathrm{M}+\mathrm{H}]^{+}$, 280.1696; found 280.1676.

(2S)-N-(2-Methoxybenzyl)-2', $3^{\prime}$-dihydrospiro[cyclopropane-1, $\mathbf{1}^{\prime}$ inden]-2-amine (14b). This compound was obtained from $\mathbf{8 b}$ and 
2-methoxybenzaldehyde according to the methodology described for 13a. Yellow oil; yield $62 \% .{ }^{1} \mathrm{H}$ NMR $\left(400 \mathrm{MHz}, \mathrm{CDCl}_{3}\right) \delta 7.22-$ $7.16(\mathrm{~m}, 2 \mathrm{H}), 7.13-7.10(\mathrm{~m}, 3 \mathrm{H}), 7.04-7.01$ (m, 1H), 6.86-6.82 (m, $1 \mathrm{H}), 6.78(\mathrm{~d}, J=8.0 \mathrm{~Hz}, 1 \mathrm{H}), 3.76(\mathrm{~s}, 3 \mathrm{H}), 3.61-3.44(\mathrm{~m}, 2 \mathrm{H}), 3.06-$ $2.89(\mathrm{~m}, 2 \mathrm{H}), 2.39$ (dd, $J=6.8,5.2 \mathrm{~Hz}, 1 \mathrm{H}), 2.18-1.81(\mathrm{~m}, 3 \mathrm{H})$, 1.04-1.00 (m, 2H). ${ }^{13} \mathrm{C}$ NMR (101 MHz, $\left.\mathrm{CDCl}_{3}\right) \delta$ 157.6, 145.1, 144.2, 130.0, 128.6, 128.0, 125.5, 125.5, 123.9, 122.4, 120.2, 110.0, 55.1, 48.7, 44.7, 35.7, 33.7, 30.8, 20.7. HRMS (ESI): calcd for $\mathrm{C}_{19} \mathrm{H}_{22} \mathrm{NO}[\mathrm{M}+\mathrm{H}]^{+}, 280.1696$; found 280.1707.

(2R)- $N$-(2-Fluorobenzyl)-2', $3^{\prime}$-dihydrospiro[cyclopropane-1,1'inden]-2-amine (15a). This compound was obtained from $\mathbf{8 a}$ and 2-fluorobenzaldehyde according to the methodology described for 13a. Yellow oil; yield $52 \%$. ${ }^{1} \mathrm{H}$ NMR $(400 \mathrm{MHz}$, $\left.\mathrm{CDCl}_{3}\right) \delta$ 7.30-7.26 (m, 1H), 7.24-7.16 (m, 2H), 7.12-6.98 (m, $4 \mathrm{H}), 6.62-6.58(\mathrm{~m}, 1 \mathrm{H}), 3.92-3.81(\mathrm{~m}, 2 \mathrm{H}), 3.07-2.92(\mathrm{~m}, 2 \mathrm{H})$, 2.41-2.30 (m, 2H), 2.15-2.10 (m, 1H), $1.80(\mathrm{~s}, 1 \mathrm{H}), 1.17-0.85(\mathrm{~m}$, 2H). $\left.{ }^{13} \mathrm{C} \mathrm{NMR} \mathrm{(101} \mathrm{MHz,} \mathrm{CDCl}_{3}\right) \delta 161.3\left(\mathrm{~d}, J_{\mathrm{C}-\mathrm{F}}=246.5 \mathrm{~Hz}\right)$, 147.8, 143.9, $130.6\left(\mathrm{~d}, J_{\mathrm{C}-\mathrm{F}}=4.9 \mathrm{~Hz}\right), 128.8\left(\mathrm{~d}, J_{\mathrm{C}-\mathrm{F}}=8.2 \mathrm{~Hz}\right)$, $127.4\left(\mathrm{~d}, J_{\mathrm{C}-\mathrm{F}}=15.3 \mathrm{~Hz}\right), 126.4,125.9,124.3,124.1\left(\mathrm{~d}, J_{\mathrm{C}-\mathrm{F}}=3.5\right.$ $\mathrm{Hz}), 118.5,115.4\left(\mathrm{~d}, J_{\mathrm{C}-\mathrm{F}}=21.9 \mathrm{~Hz}\right), 47.5\left(\mathrm{~d}, J_{\mathrm{C}-\mathrm{F}}=2.9 \mathrm{~Hz}\right), 44.7$, 33.7, 31.0, 28.4, 22.2. HRMS (ESI): calcd for $\mathrm{C}_{18} \mathrm{H}_{19} \mathrm{FN}[\mathrm{M}+\mathrm{H}]^{+}$, 268.1496; found 268.1499.

(2S)-N-(2-Fluorobenzyl)-2', $3^{\prime}$-dihydrospiro[cyclopropane-1, $\mathbf{1}^{\prime}$ inden]-2-amine (15b). This compound was obtained from $\mathbf{8 b}$ and 2-fluorobenzaldehyde according to the methodology described for 13a. Yellow oil; yield $60 \%$. ${ }^{1} \mathrm{H}$ NMR $(400 \mathrm{MHz}$, $\left.\mathrm{CDCl}_{3}\right) \delta$ 7.22-7.09 (m, 6H), 7.03-6.93 (m, 2H), 3.66-3.48 (m, $2 \mathrm{H}), 3.06-2.90(\mathrm{~m}, 2 \mathrm{H}), 2.41$ (dd, $J=7.0,4.6 \mathrm{~Hz}, 1 \mathrm{H}), 2.20-1.81$ $(\mathrm{m}, 2 \mathrm{H}), 1.65(\mathrm{~s}, 1 \mathrm{H}), 1.06-1.00(\mathrm{~m}, 2 \mathrm{H}) .{ }^{13} \mathrm{C}$ NMR $(101 \mathrm{MHz}$, $\left.\mathrm{CDCl}_{3}\right) \delta 161.3\left(\mathrm{~d}, J_{\mathrm{C}-\mathrm{F}}=246.4 \mathrm{~Hz}\right), 145.2,144.0,130.8\left(\mathrm{~d}, J_{\mathrm{C}-\mathrm{F}}=\right.$ $5.0 \mathrm{~Hz}), 128.6\left(\mathrm{~d}, J_{\mathrm{C}-\mathrm{F}}=8.1 \mathrm{~Hz}\right), 127.4\left(\mathrm{~d}, J_{\mathrm{C}-\mathrm{F}}=15.4 \mathrm{~Hz}\right), 125.8$, $125.7,124.1,123.9\left(\mathrm{~d}, J_{\mathrm{C}-\mathrm{F}}=3.5 \mathrm{~Hz}\right), 122.5,115.2\left(\mathrm{~d}, J_{\mathrm{C}-\mathrm{F}}=22.0\right.$ $\mathrm{Hz}), 46.8\left(\mathrm{~d}, J_{\mathrm{C}-\mathrm{F}}=2.8 \mathrm{~Hz}\right), 44.6,35.6,33.9,30.9,20.8$. HRMS (ESI): calcd for $\mathrm{C}_{18} \mathrm{H}_{19} \mathrm{FN}[\mathrm{M}+\mathrm{H}]^{+}$, 268.1496; found 268.1502.

(2R)- $N$-(5-Bromo-2-methoxybenzyl)-2' $3^{\prime}$-dihydrospiro[cyclopropane-1,1'-inden]-2-amine (16a). This compound was obtained from 8a and 5-bromo-2-methoxybenzaldehyde according to the methodology described for 13a. Yellow oil; yield $57 \% .{ }^{1} \mathrm{H}$ NMR (400 MHz, $\mathrm{CDCl}_{3}$ ) $\delta 7.34-7.29(\mathrm{~m}, 2 \mathrm{H}), 7.20-7.18(\mathrm{~m}, 1 \mathrm{H})$, $7.12-7.07(\mathrm{~m}, 2 \mathrm{H}), 6.69(\mathrm{~d}, J=8.8 \mathrm{~Hz}, 1 \mathrm{H}), 6.62-6.58(\mathrm{~m}, 1 \mathrm{H})$, $3.86-3.67(\mathrm{~m}, 5 \mathrm{H}), 3.08-2.93(\mathrm{~m}, 2 \mathrm{H}), 2.40-2.33(\mathrm{~m}, 1 \mathrm{H}), 2.27$ (dd, $J=7.2,4.8 \mathrm{~Hz}, 1 \mathrm{H}), 2.15-2.08(\mathrm{~m}, 1 \mathrm{H}), 2.03-2.00(\mathrm{~m}, 1 \mathrm{H})$, 1.17-0.85 (m, 2H). $\left.{ }^{13} \mathrm{C} \mathrm{NMR} \mathrm{(101} \mathrm{MHz,} \mathrm{CDCl}_{3}\right) \delta 156.7,147.8$, $143.8,132.4,130.8,130.7,126.3,125.7,124.2,118.5,112.7$, 111.9, 55.4, 48.6, 44.6, 33.6, 30.8, 28.3, 22.0. HRMS (ESI): calcd for $\mathrm{C}_{19} \mathrm{H}_{21} \mathrm{BrNO}[\mathrm{M}+\mathrm{H}]^{+}$, 358.0801; found 358.0768.

(2S)- $N$-(5-Bromo-2-methoxybenzyl)-2', $3^{\prime}$-dihydrospiro[cyclopropane-1,1'-inden]-2-amine (16b). This compound was obtained from $\mathbf{8 b}$ and 5-bromo-2-methoxybenzaldehyde according to the methodology described for 13a. Yellow oil; yield $67 \%$. ${ }^{1} \mathrm{H}$ NMR (400 $\left.\mathrm{MHz}, \mathrm{CDCl}_{3}\right) \delta 7.26-7.23(\mathrm{~m}, 1 \mathrm{H})$, 7.19-7.16 (m, 1H), 7.14-7.07 (m, 4H), $6.61(\mathrm{~d}, J=8.4 \mathrm{~Hz}, 1 \mathrm{H})$, $3.72(\mathrm{~s}, 3 \mathrm{H}), 3.60-3.36(\mathrm{~m}, 2 \mathrm{H}), 3.05-2.89(\mathrm{~m}, 2 \mathrm{H}), 2.36(\mathrm{dd}, J=$ $6.8,4.8 \mathrm{~Hz}, 1 \mathrm{H}), 2.20-1.80(\mathrm{~m}, 3 \mathrm{H}), 1.05-0.98(\mathrm{~m}, 2 \mathrm{H}) .{ }^{13} \mathrm{C}$ NMR $\left(101 \mathrm{MHz}, \mathrm{CDCl}_{3}\right) \delta 156.5,145.1,143.9,132.6,130.8,130.5$, $125.6,125.5,123.9,122.3,112.4,111.7,55.3,48.2,44.7,35.5$,
33.8, 30.8, 20.5. HRMS (ESI): calcd for $\mathrm{C}_{19} \mathrm{H}_{21} \mathrm{BrNO}[\mathrm{M}+\mathrm{H}]^{+}$, 358.0801 ; found 358.0795 .

(2R)- $N$-(5-Fluoro-2-methoxybenzyl)-2' ${ }^{\prime}, 3^{\prime}$-dihydrospiro[cyclopropane-1,1'-inden]-2-amine (17a). This compound was obtained from $\mathbf{8 a}$ and 5-fluoro-2-methoxybenzaldehyde according to the methodology described for 13a. Yellow oil; yield $65 \%$. ${ }^{1} \mathrm{H}$ NMR $\left(400 \mathrm{MHz}, \mathrm{CDCl}_{3}\right) \delta 7.21-7.17(\mathrm{~m}, 1 \mathrm{H})$, 7.11-7.07 (m, 2H), 6.97 (dd, $J=8.6,3.0 \mathrm{~Hz}, 1 \mathrm{H}), 6.91-6.86(\mathrm{~m}$, $1 \mathrm{H}), 6.73$ (dd, $J=8.8,4.4 \mathrm{~Hz}, 1 \mathrm{H}), 6.61-6.57$ (m, 1H), 3.88-3.68 $(\mathrm{m}, 5 \mathrm{H}), 3.08-2.94(\mathrm{~m}, 2 \mathrm{H}), 2.42-2.35(\mathrm{~m}, 1 \mathrm{H}), 2.28(\mathrm{dd}, J=7.4$, $4.6 \mathrm{~Hz}, 1 \mathrm{H}), 2.15-2.08(\mathrm{~m}, 1 \mathrm{H}), 1.93(\mathrm{~s}, 1 \mathrm{H}), 1.16-0.85(\mathrm{~m}, 2 \mathrm{H})$. ${ }^{13} \mathrm{C} \mathrm{NMR}\left(101 \mathrm{MHz}, \mathrm{CDCl}_{3}\right) \delta 156.9\left(\mathrm{~d}, J_{\mathrm{C}-\mathrm{F}}=239.3 \mathrm{~Hz}\right), 153.6$ $\left(\mathrm{d}, J_{\mathrm{C}-\mathrm{F}}=1.9 \mathrm{~Hz}\right), 147.9,143.8,130.3\left(\mathrm{~d}, J_{\mathrm{C}-\mathrm{F}}=6.7 \mathrm{~Hz}\right), 126.3$, $125.7,124.2,118.5,116.5\left(\mathrm{~d}, J_{\mathrm{C}-\mathrm{F}}=23.2 \mathrm{~Hz}\right), 113.6\left(\mathrm{~d}, J_{\mathrm{C}-\mathrm{F}}=\right.$ $22.8 \mathrm{~Hz}), 110.9\left(\mathrm{~d}, J_{\mathrm{C}-\mathrm{F}}=8.2 \mathrm{~Hz}\right), 55.6,48.8\left(\mathrm{~d}, J_{\mathrm{C}-\mathrm{F}}=0.7 \mathrm{~Hz}\right)$, 44.6, 33.6, 30.9, 28.3, 22.0. HRMS (ESI): calcd for $\mathrm{C}_{19} \mathrm{H}_{21} \mathrm{FNO}$ $[\mathrm{M}+\mathrm{H}]^{+}, 298.1602$; found 298.1593.

(2S)- $N$-(5-Fluoro-2-methoxybenzyl)-2', $3^{\prime}$-dihydrospiro[cyclopropane-1, $\mathbf{1}^{\prime}$-inden]-2-amine (17b). This compound was obtained from $\mathbf{8 b}$ and 5-fluoro-2-methoxybenzaldehyde according to the methodology described for 13a. Yellow oil; yield $70 \%$. ${ }^{1} \mathrm{H}$ NMR (400 $\left.\mathrm{MHz}, \mathrm{CDCl}_{3}\right) \delta 7.23-7.21(\mathrm{~m}, 1 \mathrm{H})$, 7.17-7.14 (m, 3H), 6.90-6.80 (m, 2H), $6.71(\mathrm{dd}, J=8.8,4.4 \mathrm{~Hz}$, $1 \mathrm{H}), 3.76(\mathrm{~s}, 3 \mathrm{H}), 3.64-3.42(\mathrm{~m}, 2 \mathrm{H}), 3.09-2.93(\mathrm{~m}, 2 \mathrm{H}), 2.42$ (dd, $J=6.8,4.8 \mathrm{~Hz}, 1 \mathrm{H}), 2.23-1.84(\mathrm{~m}, 3 \mathrm{H}), 1.09-1.03(\mathrm{~m}, 2 \mathrm{H})$. ${ }^{13} \mathrm{C}$ NMR $\left(101 \mathrm{MHz}, \mathrm{CDCl}_{3}\right) \delta 156.8\left(\mathrm{~d}, J_{\mathrm{C}-\mathrm{F}}=239.0 \mathrm{~Hz}\right), 153.6$ $\left(\mathrm{d}, J_{\mathrm{C}-\mathrm{F}}=2.0 \mathrm{~Hz}\right), 145.1,144.0,130.4\left(\mathrm{~d}, J_{\mathrm{C}-\mathrm{F}}=6.7 \mathrm{~Hz}\right), 125.7$, 125.6, 124.0, 122.4, $116.6\left(\mathrm{~d}, J_{\mathrm{C}-\mathrm{F}}=23.1 \mathrm{~Hz}\right), 113.4\left(\mathrm{~d}, J_{\mathrm{C}-\mathrm{F}}=\right.$ $22.9 \mathrm{~Hz}), 110.7\left(\mathrm{~d}, J_{\mathrm{C}-\mathrm{F}}=8.3 \mathrm{~Hz}\right), 55.7,48.3\left(\mathrm{~d}, J_{\mathrm{C}-\mathrm{F}}=0.8 \mathrm{~Hz}\right)$. 44.7, 35.6, 33.8, 30.8, 20.7. HRMS (ESI): calcd for $\mathrm{C}_{19} \mathrm{H}_{21} \mathrm{FNO}$ $[\mathrm{M}+\mathrm{H}]^{+}, 298.1602$; found 298.1584 .

(2R)- $N$-(4-Fluoro-2-methoxybenzyl)-2', $3^{\prime}$-dihydrospiro[cyclopropane-1,1'-inden]-2-amine (18a). This compound was obtained from $\mathbf{8 a}$ and 4-fluoro-2-methoxybenzaldehyde according to the methodology described for 13a. Yellow oil; yield $71 \%$. ${ }^{1} \mathrm{H}$ NMR (400 $\left.\mathrm{MHz}, \mathrm{CDCl}_{3}\right) \delta 7.19-7.17(\mathrm{~m}, 1 \mathrm{H})$, 7.14-7.07 (m, 3H), 6.59-6.56 (m, 2H), 6.54-6.53 (m, 1H), 3.83$3.70(\mathrm{~m}, 5 \mathrm{H}), 3.07-2.92(\mathrm{~m}, 2 \mathrm{H}), 2.40-2.33(\mathrm{~m}, 1 \mathrm{H}), 2.25(\mathrm{dd}, J=$ 7.6, $4.8 \mathrm{~Hz}, 1 \mathrm{H}), 2.14-2.07(\mathrm{~m}, 1 \mathrm{H}), 1.97$ (s, 1H), 1.15-0.84 (m, 2H). ${ }^{13} \mathrm{C} \mathrm{NMR}\left(101 \mathrm{MHz}, \mathrm{CDCl}_{3}\right) \delta 161.9\left(\mathrm{~d}, J_{\mathrm{C}-\mathrm{F}}=245.2 \mathrm{~Hz}\right)$, $157.6\left(\mathrm{~d}, J_{\mathrm{C}-\mathrm{F}}=9.8 \mathrm{~Hz}\right), 146.9,142.7,129.6\left(\mathrm{~d}, J_{\mathrm{C}-\mathrm{F}}=9.9 \mathrm{~Hz}\right)$, $125.3,124.6,123.2,123.1\left(\mathrm{~d}, J_{\mathrm{C}-\mathrm{F}}=3.3 \mathrm{~Hz}\right), 117.4,105.3\left(\mathrm{~d}, J_{\mathrm{C}-\mathrm{F}}\right.$ $=21.0 \mathrm{~Hz}$ ), $97.7\left(\mathrm{~d}, J_{\mathrm{C}-\mathrm{F}}=25.9 \mathrm{~Hz}\right) .54 .3$, 47.6, 43.6, 32.5, 29.8, 27.2, 20.9. HRMS (ESI): calcd for $\mathrm{C}_{19} \mathrm{H}_{21} \mathrm{FNO}[\mathrm{M}+\mathrm{H}]^{+}$, 298.1602; found 298.1606.

(2S)-N-(4-Fluoro-2-methoxybenzyl)-2', $3^{\prime}$-dihydrospiro[cyclopropane-1,1'-inden]-2-amine (18b). This compound was obtained from $\mathbf{8 b}$ and 4-fluoro-2-methoxybenzaldehyde according to the methodology described for 13a. Yellow oil; yield $66 \% .{ }^{1} \mathrm{H}$ NMR $\left(400 \mathrm{MHz}, \mathrm{CDCl}_{3}\right) \delta 7.19-7.17(\mathrm{~m}, 1 \mathrm{H})$, $7.14-7.07(\mathrm{~m}, 3 \mathrm{H}), 6.27(\mathrm{t}, J=7.6 \mathrm{~Hz}, 1 \mathrm{H}), 6.54-6.47(\mathrm{~m}, 2 \mathrm{H})$, $3.72(\mathrm{~s}, 3 \mathrm{H}), 3.59-3.36(\mathrm{~m}, 2 \mathrm{H}), 3.03-2.88(\mathrm{~m}, 2 \mathrm{H}), 2.37$ (dd, $J=$ $6.8,4.8 \mathrm{~Hz}, 1 \mathrm{H}), 2.19-2.12(\mathrm{~m}, 1 \mathrm{H}), 1.92(\mathrm{~s}, 1 \mathrm{H}), 1.85-1.79(\mathrm{~m}$, 1H), 1.05-1.00 (m, 2H). $\left.{ }^{13} \mathrm{C} \mathrm{NMR} \mathrm{(101} \mathrm{MHz,} \mathrm{CDCl}_{3}\right) \delta 161.8(\mathrm{~d}$, $\left.J_{\mathrm{C}-\mathrm{F}}=244.9 \mathrm{~Hz}\right), 157.5\left(\mathrm{~d}, J_{\mathrm{C}-\mathrm{F}}=9.7 \mathrm{~Hz}\right), 144.1,143.0,129.6(\mathrm{~d}$, $\left.J_{\mathrm{C}-\mathrm{F}}=9.8 \mathrm{~Hz}\right), 124.6,124.5,123.0\left(\mathrm{~d}, J_{\mathrm{C}-\mathrm{F}}=2.8 \mathrm{~Hz}\right), 122.9$, 121.2, $105.1\left(\mathrm{~d}, J_{\mathrm{C}-\mathrm{F}}=20.9 \mathrm{~Hz}\right), 97.6\left(\mathrm{~d}, J_{\mathrm{C}-\mathrm{F}}=26.0 \mathrm{~Hz}\right), 54.3$, 
47.1, 43.7, 34.6, 32.7, 29.8, 19.4. HRMS (ESI): calcd for $\mathrm{C}_{19} \mathrm{H}_{21} \mathrm{FNO}[\mathrm{M}+\mathrm{H}]^{+}, 298.1602$; found 298.1599.

(2R)- $N$-(3,4-Fimethoxybenzyl)-2', $3^{\prime}$-dihydrospiro[cyclopropane1,1'-inden]-2-amine (19a). This compound was obtained from $\mathbf{8 a}$ and 3,4-dimethoxybenzaldehyde according to the methodology described for 13a. Yellow oil; yield 46\%. ${ }^{1} \mathrm{H}$ NMR $(400 \mathrm{MHz}$, $\left.\mathrm{CDCl}_{3}\right) \delta$ 7.19-7.16 (m, 1H), 7.12-7.07 (m, 2H), 6.84-6.78 (m, 3H), 6.63-6.59 (m, 1H), $3.85(\mathrm{~s}, 3 \mathrm{H}), 3.79-3.73(\mathrm{~m}, 5 \mathrm{H}), 3.07-2.90(\mathrm{~m}$, $2 \mathrm{H}), 2.37-2.30(\mathrm{~m}, 2 \mathrm{H}), 2.17-2.08(\mathrm{~m}, 1 \mathrm{H}), 2.04-1.96(\mathrm{~m}, 1 \mathrm{H})$, 1.18-0.85 (m, 2H). ${ }^{13} \mathrm{C}$ NMR (101 MHz, $\left.\mathrm{CDCl}_{3}\right) \delta$ 148.8, 148.0, 147.8, 143.7, 133.0, 126.3, 125.7, 124.2, 120.3, 118.4, 111.7, 111.1, 56.0, 55.7, 53.8, 44.9, 33.5, 30.8, 28.4, 21.9. HRMS (ESI): calcd for $\mathrm{C}_{20} \mathrm{H}_{24} \mathrm{NO}_{2}[\mathrm{M}+\mathrm{H}]^{+}, 310.1807$; found 310.1787.

(2S)-N-(3,4-Fimethoxybenzyl)-2', $3^{\prime}$-dihydrospiro[cyclopropane1, $\mathbf{1}^{\prime}$-inden]-2-amine (19b). This compound was obtained from $\mathbf{8 b}$ and 3,4-dimethoxybenzaldehyde according to the methodology described for 13a. Yellow oil; yield 51\%. ${ }^{1} \mathrm{H}$ NMR $(400 \mathrm{MHz}$, $\left.\mathrm{CDCl}_{3}\right) \delta 7.23-7.21(\mathrm{~m}, 1 \mathrm{H}), 7.16-7.13(\mathrm{~m}, 3 \mathrm{H}), 6.75(\mathrm{~d}, J=8.4 \mathrm{~Hz}$, $1 \mathrm{H}), 6.68-6.65(\mathrm{~m}, 2 \mathrm{H}), 3.85-3.84(\mathrm{~m}, 6 \mathrm{H}), 3.54-3.27(\mathrm{~m}, 2 \mathrm{H})$, 3.09-2.93 (m, 2H), 2.46 (dd, $J=6.8,4.8 \mathrm{~Hz}, 1 \mathrm{H}), 2.26-2.18(\mathrm{~m}$, 1H), 1.89-1.83 (m, 2H), 1.10-1.04 (m, 2H). ${ }^{13} \mathrm{C}$ NMR (101 MHz, $\left.\mathrm{CDCl}_{3}\right) \delta 148.8,147.9,145.2,143.8,133.0,125.7,125.4,124.0$, 122.2, 120.3, 111.7, 110.8, 55.9, 55.8, 53.3, 44.8, 35.6, 33.8, 30.8, 20.0. HRMS (ESI): calcd for $\mathrm{C}_{20} \mathrm{H}_{24} \mathrm{NO}_{2}[\mathrm{M}+\mathrm{H}]^{+}, 310.1807$; found 310.1787 .

(2R)-N-(2-Chloro-3,4-dimethoxybenzyl)-2' $3^{\prime}$-dihydrospiro [cyclopropane-1,1'-inden]-2-amine (20a). This compound was obtained from 8a and 2-chloro-3,4-dimethoxybenzaldehyde according to the methodology described for 13a. Yellow oil; yield $64 \%$. ${ }^{1} \mathrm{H}$ NMR $\left(400 \mathrm{MHz}, \mathrm{CDCl}_{3}\right) \delta 7.21-7.19(\mathrm{~m}, 1 \mathrm{H}), 7.14-$ $7.09(\mathrm{~m}, 2 \mathrm{H}), 7.02(\mathrm{~d}, J=8.4 \mathrm{~Hz}, 1 \mathrm{H}), 6.76(\mathrm{~d}, J=8.4 \mathrm{~Hz}, 1 \mathrm{H})$, 6.64-6.60 (m, 1H), 3.93-3.83 (m, 8H), 3.10-2.95 (m, 2H), 2.44$2.37(\mathrm{~m}, 1 \mathrm{H}), 2.31$ (dd, $J=7.2,4.8 \mathrm{~Hz}, 1 \mathrm{H}), 2.18-2.10(\mathrm{~m}, 1 \mathrm{H})$, 1.91 (s, 1H), 1.19-0.88 (m, 2H). ${ }^{13} \mathrm{C} \mathrm{NMR} \mathrm{(101} \mathrm{MHz,} \mathrm{CDCl}_{3}$ ) $\delta 151.8,146.7,144.6,142.8,129.7,127.2,125.3,124.7,124.0$, 123.2, 117.4, 109.2, 60.0, 55.1, 50.3, 43.4, 32.6, 29.8, 27.3, 21.0. HRMS (ESI): calcd for $\mathrm{C}_{20} \mathrm{H}_{23} \mathrm{ClNO}_{2}[\mathrm{M}+\mathrm{H}]^{+}, 344.1412$; found 344.1390 .

(2S)- $N$-(2-Chloro-3,4-dimethoxybenzyl)-2', $3^{\prime}$-dihydrospiro [cyclopropane-1, $\mathbf{1}^{\prime}$-inden]-2-amine (20b). This compound was obtained from $\mathbf{8 b}$ and 2-chloro-3,4-dimethoxybenzaldehyde according to the methodology described for 13a. Yellow oil; yield 68\%. ${ }^{1} \mathrm{H}$ NMR $\left(400 \mathrm{MHz}, \mathrm{CDCl}_{3}\right) \delta 7.19-7.18(\mathrm{~m}, 1 \mathrm{H}), 7.13-$ $7.10(\mathrm{~m}, 3 \mathrm{H}), 6.81(\mathrm{~d}, J=8.4 \mathrm{~Hz}, 1 \mathrm{H}), 6.71(\mathrm{~d}, J=8.4 \mathrm{~Hz}, 1 \mathrm{H})$, $3.83(\mathrm{~s}, 6 \mathrm{H}), 3.65-3.48(\mathrm{~m}, 2 \mathrm{H}), 3.08-2.91(\mathrm{~m}, 2 \mathrm{H}), 2.39(\mathrm{dd}, J=$ 6.8, $4.8 \mathrm{~Hz}, 1 \mathrm{H}), 2.20-1.82(\mathrm{~m}, 2 \mathrm{H}), 1.76(\mathrm{~s}, 1 \mathrm{H}), 1.06-1.00(\mathrm{~m}$, 2H). ${ }^{13} \mathrm{C}$ NMR (101 MHz, $\mathrm{CDCl}_{3}$ ) $\delta$ 152.6, 145.4, 145.1, 144.0, 130.9, 128.3, 125.7, 125.6, 125.2, 123.9, 122.5, 110.2, 60.6, 56.1, 50.8, 44.5, 35.6, 33.9, 30.9, 20.8. HRMS (ESI): calcd for $\mathrm{C}_{20} \mathrm{H}_{23} \mathrm{ClNO}_{2}[\mathrm{M}+\mathrm{H}]^{+}$, 344.1412; found 344.1402.

(2R)- $N$-(Pyridin-3-ylmethyl)-2' ${ }^{\prime} 3^{\prime}$-dihydrospiro[cyclopropane1,1'-inden]-2-amine (21a). This compound was obtained from 8a and nicotinaldehyde according to the methodology described for 13a. Yellow oil; yield $40 \%$. ${ }^{1} \mathrm{H}$ NMR $(400 \mathrm{MHz}$, $\left.\mathrm{CD}_{3} \mathrm{OD}\right) \delta 8.47(\mathrm{~d}, J=2.0 \mathrm{~Hz}, 1 \mathrm{H}), 8.40(\mathrm{dd}, J=5.0,1.4 \mathrm{~Hz}, 1 \mathrm{H})$, $7.80-7.78(\mathrm{~m}, 1 \mathrm{H}), 7.35$ (dd, $J=8.0,4.8 \mathrm{~Hz}, 1 \mathrm{H}), 7.14-7.11(\mathrm{~m}$, 1H), 7.07-7.02 (m, 2H), 6.62-6.58 (m, 1H), $3.83(\mathrm{~s}, 2 \mathrm{H}), 3.02-$ $2.84(\mathrm{~m}, 2 \mathrm{H}), 2.32-2.25(\mathrm{~m}, 2 \mathrm{H}), 2.12-2.04(\mathrm{~m}, 1 \mathrm{H}), 1.17-0.81$ $(\mathrm{m}, 2 \mathrm{H}) .{ }^{13} \mathrm{C}$ NMR (101 MHz, CD $\left.\mathrm{OD}\right) \delta 150.3,148.6,148.5$, 144.6, 138.6, 137.5, 127.4, 126.8, 125.1, 125.1, 119.4, 51.8, 45.9, 34.2 , 31.6, 29.5, 22.0. HRMS (ESI): calcd for $\mathrm{C}_{17} \mathrm{H}_{19} \mathrm{~N}_{2}[\mathrm{M}+\mathrm{H}]^{+}$, 251.1543; found 251.1521.

(2S)- $N$-(Pyridin-3-ylmethyl)-2', $3^{\prime}$-dihydrospiro[cyclopropane1,1'-inden]-2-amine (21b). This compound was synthesized from $\mathbf{8 b}$ according to the methodology described for 13a. Yellow oil; yield 60\%. ${ }^{1} \mathrm{H}$ NMR (400 MHz, $\left.\mathrm{CD}_{3} \mathrm{OD}\right) \delta 8.30$ (dd, $J$ $=4.8,1.6 \mathrm{~Hz}, 1 \mathrm{H}), 8.20(\mathrm{~d}, J=2.0 \mathrm{~Hz}, 1 \mathrm{H}), 7.51-7.48(\mathrm{~m}, 1 \mathrm{H})$, 7.23-7.20 (m, 1H), 7.15-7.05 (m, 4H), 3.57-3.24 (m, 2H), 2.97$2.83(\mathrm{~m}, 2 \mathrm{H}), 2.41(\mathrm{dd}, J=7.2,4.8 \mathrm{~Hz}, 1 \mathrm{H}), 2.20-1.76(\mathrm{~m}, 2 \mathrm{H})$, 1.07-1.02 (m, 2H). ${ }^{13} \mathrm{C}$ NMR (101 MHz, $\left.\mathrm{CD}_{3} \mathrm{OD}\right) \delta 150.0,148.4$, $146.3,144.5$, 138.3, 137.4, 126.9, 126.6, 125.0, 124.8, 123.0, 51.4, 46.0, 36.7, 34.8, 31.5, 19.6. HRMS (ESI): calcd for $\mathrm{C}_{17} \mathrm{H}_{19} \mathrm{~N}_{2}$ $[\mathrm{M}+\mathrm{H}]^{+}, 251.1543$; found 251.1537 .

(2R)- $N$-((2-Methoxypyridin-3-yl)methyl)-2', $3^{\prime}$-dihydrospiro [cyclopropane-1,1'-inden]-2-amine (22a). This compound was obtained from 8a and 2-methoxynicotinaldehyde according to the methodology described for 13a. Yellow oil; yield $61 \% .{ }^{1} \mathrm{H}$ NMR (400 MHz, $\mathrm{CDCl}_{3}$ ) $\delta 8.07-8.05(\mathrm{~m}, 1 \mathrm{H}), 7.47$ (d, $J=7.2 \mathrm{~Hz}$, $1 \mathrm{H}), 7.20-7.18(\mathrm{~m}, 1 \mathrm{H}), 7.12-7.07(\mathrm{~m}, 2 \mathrm{H}), 6.81$ (dd, $J=7.0$, $5.4 \mathrm{~Hz}, 1 \mathrm{H}), 6.59(\mathrm{t}, J=4.2 \mathrm{~Hz}, 1 \mathrm{H}), 3.91(\mathrm{~s}, 3 \mathrm{H}), 3.84-3.72(\mathrm{~m}$, $2 \mathrm{H}), 3.09-2.93(\mathrm{~m}, 2 \mathrm{H}), 2.41-2.34(\mathrm{~m}, 1 \mathrm{H}), 2.29-2.26(\mathrm{~m}, 1 \mathrm{H})$, 2.16-2.09 (m, 3H), 1.17-1.14 (m, 1H). ${ }^{13} \mathrm{C}$ NMR (101 MHz, $\left.\mathrm{CDCl}_{3}\right) \delta 162.1,147.8,145.3,143.7,137.8,126.3,125.8,124.2$, 122.6, 118.4, 116.7, 53.3, 48.7, 44.5, 33.5, 30.8, 28.3, 22.0. HRMS (ESI): calcd for $\mathrm{C}_{18} \mathrm{H}_{21} \mathrm{~N}_{2} \mathrm{O}[\mathrm{M}+\mathrm{H}]^{+}, 281.1648$; found 281.1654.

(2S)- $N$-((2-Methoxypyridin-3-yl)methyl)-2' ${ }^{\prime}, 3^{\prime}$-dihydrospiro [cyclopropane-1,1'-inden]-2-amine (22b). This compound was obtained from $\mathbf{8 b}$ and 2-methoxynicotinaldehyde according to the methodology described for 13a. Yellow oil; yield $50 \% .{ }^{1} \mathrm{H}$ NMR (400 MHz, $\left.\mathrm{CD}_{3} \mathrm{OD}\right) \delta 7.91(\mathrm{~d}, J=4.4 \mathrm{~Hz}, 1 \mathrm{H}), 7.36-7.32(\mathrm{~m}$, $1 \mathrm{H})$, 7.13-7.06 (m, 3H), 6.99-6.97 (m, 1H), 6.81-6.77 (m, 1H), $3.82(\mathrm{~s}, 3 \mathrm{H}), 3.58-3.29(\mathrm{~m}, 2 \mathrm{H}), 2.95-2.80(\mathrm{~m}, 2 \mathrm{H}), 2.38(\mathrm{dd}, J=$ 7.0, 5.0 Hz, 1H), 2.20-1.75 (m, 2H), 1.06-0.96 (m, 2H). ${ }^{13} \mathrm{C}$ NMR (101 MHz, $\left.\mathrm{CD}_{3} \mathrm{OD}\right) \delta 163.3,146.4,146.2,144.4,139.5,127.0$, 126.7, 125.2, 123.6, 122.6, 117.9, 53.9, 46.0, 36.9, 34.7, 31.6, 19.4, 19.3. HRMS (ESI): calcd for $\mathrm{C}_{18} \mathrm{H}_{21} \mathrm{~N}_{2} \mathrm{O}[\mathrm{M}+\mathrm{H}]^{+}, 281.1648$; found 281.1665.

(2R)- $N$-((2-Fluoropyridin-3-yl)methyl)-2', $3^{\prime}$-dihydrospiro[cyclopropane-1,1'-inden]-2-amine (23a). This compound was obtained from 8a and 2-fluoronicotinaldehyde according to the methodology described for 13a. Yellow oil; yield 22\%. ${ }^{1} \mathrm{H}$ NMR $\left(400 \mathrm{MHz}, \mathrm{CDCl}_{3}\right) \delta 8.10(\mathrm{~d}, J=4.8 \mathrm{~Hz}, 1 \mathrm{H}), 7.77-7.72(\mathrm{~m}, 1 \mathrm{H})$, 7.20-7.18 (m, 1H), 7.14-7.07 (m, 3H), 6.62-6.58 (m, 1H), 3.93$3.83(\mathrm{~m}, 2 \mathrm{H}), 3.09-2.92(\mathrm{~m}, 2 \mathrm{H}), 2.39-2.30$ (m, 2H), 2.16-2.08 (m, $1 \mathrm{H}), 1.90(\mathrm{~s}, 1 \mathrm{H}), 1.19-0.85(\mathrm{~m}, 2 \mathrm{H}) .{ }^{13} \mathrm{C} \mathrm{NMR}\left(101 \mathrm{MHz}, \mathrm{CDCl}_{3}\right)$ $\delta 161.9\left(\mathrm{~d}, J_{\mathrm{C}-\mathrm{F}}=239.9 \mathrm{~Hz}\right), 147.4,146.0\left(\mathrm{~d}, J_{\mathrm{C}-\mathrm{F}}=14.9 \mathrm{~Hz}\right), 143.7$, $140.6\left(\mathrm{~d}, J_{\mathrm{C}-\mathrm{F}}=5.8 \mathrm{~Hz}\right), 126.4,125.9,124.3,122.2\left(\mathrm{~d}, J_{\mathrm{C}-\mathrm{F}}=30.0\right.$ $\mathrm{Hz}), 121.4\left(\mathrm{~d}, J_{\mathrm{C}-\mathrm{F}}=4.2 \mathrm{~Hz}\right) .118 .4,46.9,44.4$, 33.6, 30.8, 28.3, 22.0. HRMS (ESI): calcd for $\mathrm{C}_{17} \mathrm{H}_{18} \mathrm{FN}_{2}[\mathrm{M}+\mathrm{H}]^{+}, 269.1449$; found 269.1471.

(2S)-N-((2-Fluoropyridin-3-yl)methyl)-2', $3^{\prime}$-dihydrospiro[cyclopropane-1,1'-inden]-2-amine (23b). This compound was obtained from $\mathbf{8 b}$ and 2-fluoronicotinaldehyde according to the methodology described for 13a. Yellow oil; yield 30\%. ${ }^{1} \mathrm{H}$ NMR 
$\left(400 \mathrm{MHz}, \mathrm{CDCl}_{3}\right) \delta 8.03(\mathrm{~d}, J=4.8 \mathrm{~Hz}, 1 \mathrm{H}), 7.54-7.49(\mathrm{~m}, 1 \mathrm{H})$, 7.19-7.17 (m, 1H), 7.14-7.07 (m, 3H), 7.06-7.02 (m, 1H), 3.69$3.47(\mathrm{~m}, 2 \mathrm{H}), 3.03-2.89(\mathrm{~m}, 2 \mathrm{H}), 2.41(\mathrm{dd}, J=6.8,4.8 \mathrm{~Hz}, 1 \mathrm{H})$, 2.22-2.14 (m, 1H), 1.87-1.81 (m, 1H), 1.76 (s, 1H), 1.08-1.00 (m, 2H). ${ }^{13} \mathrm{C}$ NMR (101 MHz, $\left.\mathrm{CDCl}_{3}\right) \delta 161.8\left(\mathrm{~d}, J_{\mathrm{C}-\mathrm{F}}=239.7 \mathrm{~Hz}\right)$, $145.8\left(\mathrm{~d}, J_{\mathrm{C}-\mathrm{F}}=14.8 \mathrm{~Hz}\right), 145.1,143.5,140.8\left(\mathrm{~d}, J_{\mathrm{C}-\mathrm{F}}=5.9 \mathrm{~Hz}\right)$, $125.8,125.5,124.0,122.4,122.1\left(\mathrm{~d}, J_{\mathrm{C}-\mathrm{F}}=30.0 \mathrm{~Hz}\right), 121.3\left(\mathrm{~d}, J_{\mathrm{C}-\mathrm{F}}\right.$ $=4.2 \mathrm{~Hz}$ ), 46.4, 44.5, 35.4, 30.7, 29.7, 20.5. HRMS (ESI): calcd for $\mathrm{C}_{17} \mathrm{H}_{18} \mathrm{FN}_{2}[\mathrm{M}+\mathrm{H}]^{+}, 269.1449$; found 269.1448.

(2R)- $N$-((3-Fluoropyridin-2-yl)methyl)-2' $3^{\prime}$-dihydrospiro[cyclopropane-1, $\mathbf{1}^{\prime}$-inden]-2-amine (24a). This compound was obtained from 8a and 3-fluoropicolinaldehyde according to the methodology described for 13a. Yellow oil; yield 47\%. ${ }^{1} \mathrm{H}$ NMR $\left(400 \mathrm{MHz}, \mathrm{CDCl}_{3}\right) \delta 8.39-8.37(\mathrm{~m}, 1 \mathrm{H}), 7.37-7.32(\mathrm{~m}, 1 \mathrm{H}), 7.22-$ $7.18(\mathrm{~m}, 2 \mathrm{H}), 7.13-7.08(\mathrm{~m}, 2 \mathrm{H}), 6.64-6.60(\mathrm{~m}, 1 \mathrm{H}), 4.09-4.01(\mathrm{~m}$, $2 \mathrm{H}), 3.07-3.03(\mathrm{~m}, 2 \mathrm{H}), 2.47-2.36(\mathrm{~m}, 3 \mathrm{H}), 2.20-2.12(\mathrm{~m}, 1 \mathrm{H})$, 1.21-0.92 (m, 2H). ${ }^{13} \mathrm{C}$ NMR (101 MHz, $\left.\mathrm{CDCl}_{3}\right) \delta 157.5\left(\mathrm{~d}, J_{\mathrm{C}-\mathrm{F}}=\right.$ $257.6 \mathrm{~Hz}), 147.8\left(\mathrm{~d}, J_{\mathrm{C}-\mathrm{F}}=15.8 \mathrm{~Hz}\right), 147.7,144.9\left(\mathrm{~d}, J_{\mathrm{C}-\mathrm{F}}=5.3 \mathrm{~Hz}\right)$, $143.9,126.3,125.8,124.2,123.2\left(\mathrm{~d}, J_{\mathrm{C}-\mathrm{F}}=3.7 \mathrm{~Hz}\right), 122.6\left(\mathrm{~d}, J_{\mathrm{C}-\mathrm{F}}=\right.$ $19.1 \mathrm{~Hz}$ ), 118.5, 48.4, 44.7, 33.5, 30.9, 28.3, 22.1. HRMS (ESI): calcd for $\mathrm{C}_{17} \mathrm{H}_{18} \mathrm{FN}_{2}[\mathrm{M}+\mathrm{H}]^{+}, 269.1449$; found 269.1431.

(2S)-N-((3-Fluoropyridin-2-yl)methyl)-2', $3^{\prime}$-dihydrospiro[cyclopropane-1, $\mathbf{1}^{\prime}$-inden]-2-amine $(\mathbf{2 4 b})$. This compound was obtained from $\mathbf{8 b}$ and 3-fluoropicolinaldehyde according to the methodology described for 13a. Yellow oil; yield 59\%. ${ }^{1} \mathrm{H}$ NMR $\left(400 \mathrm{MHz}, \mathrm{CDCl}_{3}\right) \delta 8.30(\mathrm{~d}, J=4.8 \mathrm{~Hz}, 1 \mathrm{H}), 7.25-7.21(\mathrm{~m}, 1 \mathrm{H})$, 7.16-7.07 (m, 5H), 3.81-3.71 (m, 2H), 3.04-2.87 (m, 2H), 2.45 (dd, $J=6.8,4.8 \mathrm{~Hz}, 1 \mathrm{H}), 2.22(\mathrm{~s}, 1 \mathrm{H}), 2.17-1.82(\mathrm{~m}, 2 \mathrm{H}), 1.07-1.00(\mathrm{~m}$, 2H). $\left.{ }^{13} \mathrm{C} \mathrm{NMR} \mathrm{(101} \mathrm{MHz,} \mathrm{CDCl}_{3}\right) \delta 157.6\left(\mathrm{~d}, J_{\mathrm{C}-\mathrm{F}}=257.6 \mathrm{~Hz}\right)$, $148.1\left(\mathrm{~d}, J_{\mathrm{C}-\mathrm{F}}=15.7 \mathrm{~Hz}\right), 145.0,144.8\left(\mathrm{~d}, J_{\mathrm{C}-\mathrm{F}}=5.4 \mathrm{~Hz}\right), 143.9$, $125.6,125.5,123.9,123.1\left(\mathrm{~d}, J_{\mathrm{C}-\mathrm{F}}=3.6 \mathrm{~Hz}\right), 122.5,122.4\left(\mathrm{~d}, J_{\mathrm{C}-\mathrm{F}}=\right.$ $19.2 \mathrm{~Hz}), 48.3$, 44.8, 35.6, 33.7, 30.7, 20.8. HRMS (ESI): calcd for $\mathrm{C}_{17} \mathrm{H}_{18} \mathrm{FN}_{2}[\mathrm{M}+\mathrm{H}]^{+}, 269.1449$; found 269.1447.

2-(((2R)-2',3'-Dihydrospiro[cyclopropane-1,1'-inden]-2-yl)amino)1-morpholinoethan-1-one hydrochloride (25a). To a stirred suspension of $\mathrm{NaH}$ ( $28 \mathrm{mg}, 50 \%$ in mineral oil, $0.59 \mathrm{mmol}$ ) in anhydrous DMF $(2 \mathrm{~mL})$ at $0{ }^{\circ} \mathrm{C}$ was added a solution of 12a (100 mg, $0.39 \mathrm{mmol}$ ). After an additional $0.5 \mathrm{~h}$ stirring, 2-chloro1-morpholinoethan-1-one ( $77 \mathrm{mg}, 0.47 \mathrm{mmol}$ ) was added at $0{ }^{\circ} \mathrm{C}$ and the mixture was stirred for another $1 \mathrm{~h}$, slowly warming to rt. The reaction mixture was poured into ice-water and extracted with EtOAc $(3 \times 30 \mathrm{~mL})$. The combined organic layers were washed with water, brine, dried over anhydrous $\mathrm{Na}_{2} \mathrm{SO}_{4}$, filtered and evaporated. The crude residue was purified by flash chromatography using $\mathrm{CH}_{2} \mathrm{Cl}_{2}: \mathrm{CH}_{3} \mathrm{OH}(60: 1)$ to afford a yellow solid, which was then immediately treated with $4 \mathrm{M} \mathrm{HCl}$ in ethyl acetate $(5 \mathrm{~mL})$ and stirred at rt overnight. The precipitated solid was filtered, washed with diethyl ether and dried to afford 25a as a hydrochloride salt. Yellow solid; yield $48 \%$. ${ }^{1} \mathrm{H}$ NMR $(400$ $\left.\mathrm{MHz}, \mathrm{CD}_{3} \mathrm{OD}\right) \delta 7.24-7.16(\mathrm{~m}, 3 \mathrm{H}), 6.77(\mathrm{~d}, J=4.0 \mathrm{~Hz}, 1 \mathrm{H}), 4.31$ (s, 2H), 3.70-3.60 (m, 6H), 3.48 (s, 2H), 3.17-3.06 (m, 3H), 2.40$2.33(\mathrm{~m}, 2 \mathrm{H}), 1.45(\mathrm{~s}, 2 \mathrm{H}) .{ }^{13} \mathrm{C} \mathrm{NMR}\left(101 \mathrm{MHz}, \mathrm{CD}_{3} \mathrm{OD}\right) \delta 164.9$, 145.1, 144.8, 128.4, 128.0, 125.5, 120.1, 67.5, 67.4, 50.0, 46.3, 43.5, 42.9, 33.0, 31.7, 29.5, 19.5. HRMS (ESI): calcd for $\mathrm{C}_{17} \mathrm{H}_{23} \mathrm{~N}_{2} \mathrm{O}_{2}[\mathrm{M}+\mathrm{H}]^{+}$, 287.1754; found 287.1735.

2-(((2S)-2' ${ }^{\prime}, 3^{\prime}$-Dihydrospiro[cyclopropane-1,1'-inden]-2-yl)amino)1-morpholinoethan-1-one hydrochloride (25b). This compound was synthesized from $\mathbf{8 b}$ according to the methodology described for 25a. Yellow solid; yield 45\%. ${ }^{1} \mathrm{H}$ NMR (400 MHz, $\left.\mathrm{CD}_{3} \mathrm{OD}\right) \delta 7.36$ (d, $J=6.4 \mathrm{~Hz}, 1 \mathrm{H}), 7.30-7.20$ (m, 3H), 4.16-3.78 (m, 2H), 3.66-3.59 (m, 4H), 3.57-3.54 (m, 2H), 3.31-3.30 (m, 2H), 3.22-3.13 (m, $1 \mathrm{H})$, 3.07 (dd, $J=7.8,4.6 \mathrm{~Hz}, 1 \mathrm{H}), 3.02-2.96(\mathrm{~m}, 1 \mathrm{H}), 2.40-1.94(\mathrm{~m}, 2 \mathrm{H})$, 1.75-1.45 (m, 2H). ${ }^{13} \mathrm{C}$ NMR (101 MHz, $\left.\mathrm{CD}_{3} \mathrm{OD}\right) \delta$ 164.6, 147.6, 140.1, 129.0, 128.0, 126.5, 121.7, 67.5, 67.3, 46.2, 43.6, 42.7, 36.7, 34.0, 31.5, 15.1. HRMS (ESI): calcd for $\mathrm{C}_{17} \mathrm{H}_{22} \mathrm{~N}_{2} \mathrm{NaO}_{2}[\mathrm{M}+\mathrm{Na}]^{+}$, 309.1573; found 309.1550.

tert-Butyl ((2R)-5'-bromo-2' $\mathbf{2}^{\prime} \mathbf{3}^{\prime}$-dihydrospiro[cyclopropane1,1'-inden]-2-yl)carbamate (27a). This compound was obtained from 5-bromo-2,3-dihydro- $1 H$-inden-1-one (26) as starting material and prepared according to the methodology described for 12a. White solid; yield $24 \%$. ${ }^{1} \mathrm{H}$ NMR (400 $\mathrm{MHz}, \mathrm{CDCl}_{3}$ ) $\delta 7.31(\mathrm{~s}, 1 \mathrm{H}), 7.21(\mathrm{~d}, J=8.0 \mathrm{~Hz}, 1 \mathrm{H}), 6.50(\mathrm{~d}, J=8.0 \mathrm{~Hz}, 1 \mathrm{H})$, $4.73(\mathrm{~s}, 1 \mathrm{H}), 3.11-2.95(\mathrm{~m}, 2 \mathrm{H}), 2.69(\mathrm{~s}, 1 \mathrm{H}), 2.14-2.04(\mathrm{~m}, 2 \mathrm{H})$, 1.43 (s, 9H), 1.35-1.32 (m, 2H). ${ }^{13} \mathrm{C}$ NMR (101 MHz, $\mathrm{CDCl}_{3}$ ) $\delta$ 156.4 $146.2,145.4,129.4,127.4,119.9,119.6$, 79.7, 36.5, 32.8, 30.6, 28.9, 28.3, 21.0.

tert-Butyl ((2S)-5'-bromo- $2^{\prime}, 3^{\prime}$-dihydrospiro[cyclopropane1,1'-inden]-2-yl)carbamate (27b). This compound was obtained from 5-bromo-2,3-dihydro- $1 H$-inden-1-one (26) as starting material and prepared according to the methodology described for 12b. White solid; yield $22 \% .{ }^{1} \mathrm{H} \mathrm{NMR}\left(400 \mathrm{MHz}, \mathrm{CDCl}_{3}\right) \delta 7.35$ (s, $1 \mathrm{H}), 7.24$ (d, $J=8.4 \mathrm{~Hz}, 1 \mathrm{H}), 6.68(\mathrm{~s}, 1 \mathrm{H}), 4.56$ (s, 1H), 3.17-2.91 (m, 2H), 2.75 (s, 1H), 2.30-1.91 (m, 2H), 1.31-1.22 (m, 9H), 1.14 (s, 2H). ${ }^{13} \mathrm{C}$ NMR (101 MHz, $\left.\mathrm{CDCl}_{3}\right) \delta$ 156.1, 148.0, 141.6, 128.6, $127.5,122.5,119.9,79.4,37.2,36.1,34.9,30.6,28.2$, 19.3.

General procedure for the synthesis of $(2 R)-5^{\prime}$-phenyl-2 ${ }^{\prime}, 3^{\prime}$ dihydrospiro[cyclopropane-1, $\mathbf{1}^{\prime}$-inden]-2-amine hydrochloride (28a)

To a mixture of $27 \mathrm{a}(150 \mathrm{mg}, 0.44 \mathrm{mmol})$ and tetrakis(triphenylphosphine)palladium (25 $\mathrm{mg}, 0.022 \mathrm{mmol}$ ) in DMF (2.5 mL) was added phenylboronic acid (65 $\mathrm{mg}, 0.53 \mathrm{mmol}$ ) immediately followed by aqueous $\mathrm{Na}_{2} \mathrm{CO}_{3}$ solution $(2 \mathrm{M}, 0.4 \mathrm{~mL}$ $\mathrm{H}_{2} \mathrm{O}$ ). The mixture was stirred at $80{ }^{\circ} \mathrm{C}$ for $16 \mathrm{~h}$ under an argon atmosphere. After cooling, the reaction mixture was filtered and the filtrate was extracted with EtOAc $(3 \times 30 \mathrm{~mL})$. The combined organic layers were washed with water, dried over $\mathrm{MgSO}_{4}$, filtered, and concentrated in vacuo. The crude product was purified by flash chromatography in PE/EtOAc (25:1) to yield the pure product as a white solid. A solution of $\mathrm{HCl}$ in ethyl acetate $(4 \mathrm{M}, 5 \mathrm{~mL})$ was then added to the white solid. After stirring at room temperature overnight, the precipitated solid was filtered off, washed with diethyl ether and dried to afford 28a as a hydrochloride salt. Yellow solid; yield $63 \%$. ${ }^{1} \mathrm{H}$ NMR $\left(400 \mathrm{MHz}, \mathrm{DMSO}-d_{6}\right) \delta 8.73(\mathrm{~s}, 2 \mathrm{H}), 7.63-7.61(\mathrm{~m}, 2 \mathrm{H}), 7.51(\mathrm{~s}$, 1H), 7.46-7.42 (m, 3H), 7.36-7.32 (m, 1H), $6.93(\mathrm{~d}, J=8.0 \mathrm{~Hz}$, $1 \mathrm{H}), 3.18-3.04(\mathrm{~m}, 2 \mathrm{H}), 2.85-2.82(\mathrm{~m}, 1 \mathrm{H}), 2.37-2.17(\mathrm{~m}, 2 \mathrm{H})$, 1.38-1.35 (m, 2H). ${ }^{13} \mathrm{C}$ NMR (101 MHz, DMSO- $\left.d_{6}\right) \delta 144.4,144.3$, 140.4, 139.0, 128.9, 127.2, 126.7, 125.4, 122.5, 119.8, 33.6, 30.3, 30.1, 28.3, 18.8. HRMS (ESI): calcd for $\mathrm{C}_{17} \mathrm{H}_{18} \mathrm{~N}[\mathrm{M}+\mathrm{H}]^{+}$, 236.1439; found 236.1425.

(2S)-5' -Phenyl-2', $3^{\prime}$-dihydrospiro[cyclopropane-1,1'-inden]-2amine hydrochloride (28b). This compound was obtained from 
27b and phenylboronic acid according to the methodology described for 28a. Yellow solid; yield 62\%. ${ }^{1} \mathrm{H}$ NMR $(400 \mathrm{MHz}$, DMSO- $\left.d_{6}\right) \delta 8.36(\mathrm{~s}, 2 \mathrm{H}), 7.63(\mathrm{~d}, J=7.2 \mathrm{~Hz}, 2 \mathrm{H}), 7.57(\mathrm{~s}, 1 \mathrm{H})$, 7.46-7.43 (m, 3H), 7.38-7.31 (m, 2H), 3.13-2.92 (m, 2H), 2.87$2.84(\mathrm{~m}, 1 \mathrm{H}), 2.26-1.96(\mathrm{~m}, 2 \mathrm{H}), 1.56-1.33$ (m, 2H). ${ }^{13} \mathrm{C}$ NMR $\left(101 \mathrm{MHz}, \mathrm{DMSO}-d_{6}\right) \delta 146.8,140.5,139.9,139.4,129.1,127.5$, 126.8, 125.1, 123.2, 122.2, 35.1, 34.0, 31.2, 30.5, 16.0. HRMS (ESI): calcd for $\mathrm{C}_{17} \mathrm{H}_{18} \mathrm{~N}[\mathrm{M}+\mathrm{H}]^{+}$, 236.1439; found 236.1434.

(2R)-5' -(4-Fluorophenyl)-2' ${ }^{\prime} 3^{\prime}$-dihydrospiro[cyclopropane-1, $\mathbf{1}^{\prime}$ inden]-2-amine hydrochloride (29a). This compound was obtained from 27a and (4-fluorophenyl)boronic acid according to the methodology described for $28 \mathrm{a}$. White solid; yield $60 \%{ }^{1} \mathrm{H}$ NMR (400 MHz, DMSO- $\left.d_{6}\right) \delta 8.77(\mathrm{~s}, 2 \mathrm{H}), 7.68-7.64(\mathrm{~m}, 2 \mathrm{H}), 7.49$ $(\mathrm{s}, 1 \mathrm{H}), 7.40(\mathrm{~d}, J=8.0 \mathrm{~Hz}, 1 \mathrm{H}), 7.26(\mathrm{t}, J=8.8 \mathrm{~Hz}, 2 \mathrm{H}), 6.92(\mathrm{~d}, J$ $=8.0 \mathrm{~Hz}, 1 \mathrm{H}), 3.17-3.03(\mathrm{~m}, 2 \mathrm{H}), 2.83(\mathrm{t}, J=6.2 \mathrm{~Hz} 1 \mathrm{H}), 2.38-$ $2.17(\mathrm{~m}, 2 \mathrm{H}), 1.36-1.33(\mathrm{~m}, 2 \mathrm{H}) .{ }^{13} \mathrm{C}$ NMR (101 MHz, DMSO- $\left.d_{6}\right)$ $\delta 161.6\left(\mathrm{~d}, J_{\mathrm{C}-\mathrm{F}}=244.9 \mathrm{~Hz}\right), 144.3,144.2,137.8,136.7\left(\mathrm{~d}, J_{\mathrm{C}-\mathrm{F}}=\right.$ $3.0 \mathrm{~Hz}) .128 .4\left(\mathrm{~d}, J_{\mathrm{C}-\mathrm{F}}=8.1 \mathrm{~Hz}\right), 125.2,122.4,119.7,115.5\left(\mathrm{~d}, J_{\mathrm{C}-\mathrm{F}}\right.$ $=21.3 \mathrm{~Hz}$ ), 33.4, 30.2, 29.9, 28.2, 18.6. HRMS (ESI): calcd for $\mathrm{C}_{17} \mathrm{H}_{17} \mathrm{NF}[\mathrm{M}+\mathrm{H}]^{+}, 254.1345$; found 254.1336.

(2S)-5' -(4-Fluorophenyl)-2' ${ }^{\prime} 3^{\prime}$-dihydrospiro[cyclopropane-1,1' inden]-2-amine hydrochloride (29b). This compound was obtained from $27 \mathbf{b}$ and (4-fluorophenyl)boronic acid according to the methodology described for 28a. White solid; yield $34 \% .{ }^{1} \mathrm{H}$ NMR (400 MHz, DMSO- $\left.d_{6}\right) \delta 8.52(\mathrm{~s}, 2 \mathrm{H}), 7.71-7.67(\mathrm{~m}, 2 \mathrm{H}), 7.56$ (s, 1H), 7.48-7.43 (m, 2H), $7.28(\mathrm{t}, J=8.8 \mathrm{~Hz}, 2 \mathrm{H}), 3.12-2.94(\mathrm{~m}$, 2H), 2.86 (s, 1H), 2.27-1.98 (m, 2H), 1.64-1.32 (m, 2H). ${ }^{13} \mathrm{C}$ NMR $\left(101 \mathrm{MHz}, \mathrm{DMSO}-d_{6}\right) \delta 161.6\left(\mathrm{~d}, J_{\mathrm{C}-\mathrm{F}}=244.9 \mathrm{~Hz}\right), 146.5,139.7$, 138.0, $136.7\left(\mathrm{~d}, J_{\mathrm{C}-\mathrm{F}}=3.0 \mathrm{~Hz}\right), 128.4\left(\mathrm{~d}, J_{\mathrm{C}-\mathrm{F}}=8.2 \mathrm{~Hz}\right), 124.7$, 122.8, 122.2, $115.6\left(\mathrm{~d}, J_{\mathrm{C}-\mathrm{F}}=21.4 \mathrm{~Hz}\right), 34.8,33.7,31.0,30.3,15.8$. HRMS (ESI): calcd for $\mathrm{C}_{17} \mathrm{H}_{17} \mathrm{FN}[\mathrm{M}+\mathrm{H}]^{+}, 254.1340$; found 254.1337.

(2R)- $N$-(5-Fluoro-2-methoxybenzyl)-5' -phenyl-2', $3^{\prime}$-dihydrospiro [cyclopropane-1,1'-inden]-2-amine (30a). This compound was obtained from 28a and 5-fluoro-2-methoxybenzaldehyde according to the methodology described for 13a. Yellow oil; yield $73 \% .{ }^{1} \mathrm{H}$ NMR (400 MHz, $\left.\mathrm{CDCl}_{3}\right) \delta 7.55(\mathrm{~d}, J=7.6 \mathrm{~Hz}, 2 \mathrm{H}), 7.42-7.38(\mathrm{~m}$, $3 \mathrm{H}), 7.34-7.28(\mathrm{~m}, 2 \mathrm{H}), 7.00(\mathrm{dd}, J=8.8,3.2 \mathrm{~Hz}, 1 \mathrm{H}), 6.92-6.87(\mathrm{~m}$, $1 \mathrm{H}), 6.73(\mathrm{dd}, J=9.2,4.4 \mathrm{~Hz}, 1 \mathrm{H}), 6.66(\mathrm{~d}, J=8.0 \mathrm{~Hz}, 1 \mathrm{H}), 3.90-$ $3.72(\mathrm{~m}, 6 \mathrm{H}), 3.14-2.99$ (m, 2H), 2.47-2.41 (m, 1H), 2.34 (dd, $J=$ 7.2, $4.8 \mathrm{~Hz}, 1 \mathrm{H}), 2.22-2.14(\mathrm{~m}, 1 \mathrm{H}), 1.21-0.91(\mathrm{~m}, 2 \mathrm{H}) .{ }^{13} \mathrm{C}$ NMR $\left(101 \mathrm{MHz} \mathrm{CDCl}_{3}\right) \delta 156.0\left(\mathrm{~d}, J_{\mathrm{C}-\mathrm{F}}=239.4 \mathrm{~Hz}\right), 152.6\left(\mathrm{~d}, J_{\mathrm{C}-\mathrm{F}}=2.1\right.$ $\mathrm{Hz}), 146.1,143.5,140.6,138.2,128.9\left(\mathrm{~d}, J_{\mathrm{C}-\mathrm{F}}=6.9 \mathrm{~Hz}\right), 127.6$, 126.0, 125.8, 124.5, 122.1, 117.7, $115.6\left(\mathrm{~d}, J_{\mathrm{C}-\mathrm{F}}=23.2 \mathrm{~Hz}\right), 112.7(\mathrm{~d}$, $\left.J_{\mathrm{C}-\mathrm{F}}=22.7 \mathrm{~Hz}\right), 109.9\left(\mathrm{~d}, J_{\mathrm{C}-\mathrm{F}}=8.2 \mathrm{~Hz}\right), 54.6,47.7,43.6,32.4,29.8$, 27.5, 21.0. HRMS (ESI): calcd for $\mathrm{C}_{25} \mathrm{H}_{25} \mathrm{FNO}[\mathrm{M}+\mathrm{H}]^{+}, 374.1915$; found 374.1920 .

(2S)-N-(5-Fluoro-2-methoxybenzyl)-5' -phenyl-2', $3^{\prime}$-dihydrospiro [cyclopropane-1, $\mathbf{1}^{\prime}$-inden]-2-amine $(\mathbf{3 0 b})$. This compound was obtained from $\mathbf{2 8 b}$ and 5-fluoro-2-methoxybenzaldehyde according to the methodology described for 13a. Yellow oil; yield 55\%. ${ }^{1} \mathrm{H}$ NMR (400 MHz, $\mathrm{CDCl}_{3}$ ) $\delta 7.60-7.58(\mathrm{~m}, 2 \mathrm{H}), 7.43-7.39(\mathrm{~m}, 3 \mathrm{H})$, 7.37-7.35 (m, 1H), 7.32-7.28 (m, 1H), 7.17 (d, $J=8.0 \mathrm{~Hz}, 1 \mathrm{H})$, 6.87-6.80 (m, 2H), $6.66(\mathrm{dd}, J=8.4,4.4 \mathrm{~Hz}, 1 \mathrm{H}), 3.72(\mathrm{~s}, 3 \mathrm{H}), 3.68-$ $3.45(\mathrm{~m}, 2 \mathrm{H}), 3.09-2.95(\mathrm{~m}, 2 \mathrm{H}), 2.43(\mathrm{dd}, J=7.2,4.8 \mathrm{~Hz}, 1 \mathrm{H})$, 2.24-2.16 (m, 1H), 1.97 (s, 1H), 1.92-1.86 (m, 1H), 1.10-1.03 (m, $2 \mathrm{H}) .{ }^{13} \mathrm{C} \mathrm{NMR}\left(101 \mathrm{MHz}, \mathrm{CDCl}_{3}\right) \delta 156.8\left(\mathrm{~d}, J_{\mathrm{C}-\mathrm{F}}=239.1 \mathrm{~Hz}\right), 153.5$ $\left(\mathrm{d}, J_{\mathrm{C}-\mathrm{F}}=2.0 \mathrm{~Hz}\right), 145.8,143.4,141.8,139.0,130.2\left(\mathrm{~d}, J_{\mathrm{C}-\mathrm{F}}=6.7\right.$ $\mathrm{Hz}), 128.7,127.1,126.8,124.7,122.8,122.6,116.6$ (d, $J_{\mathrm{C}-\mathrm{F}}=23.1$ $\mathrm{Hz}), 113.5\left(\mathrm{~d}, J_{\mathrm{C}-\mathrm{F}}=22.8 \mathrm{~Hz}\right), 110.7\left(\mathrm{~d}, J_{\mathrm{C}-\mathrm{F}}=8.2 \mathrm{~Hz}\right), 55.7,48.4$, 44.8, 35.7, 33.7, 30.8, 20.8. HRMS (ESI): calcd for $\mathrm{C}_{25} \mathrm{H}_{25} \mathrm{FNO}[\mathrm{M}+$ $\mathrm{H}]^{+}, 374.1915$; found 374.1906.

(2R)-N-(2-Chloro-3,4-dimethoxybenzyl)-5' -phenyl-2', $3^{\prime}$-dihydrospiro[cyclopropane-1,1'-inden]-2-amine (31a). This compound was obtained from 28a and 2-chloro-3,4-dimethoxybenzaldehyde according to the methodology described for 13a. Yellow oil; yield $52 \% .{ }^{1} \mathrm{H}$ NMR $\left(400 \mathrm{MHz}, \mathrm{CDCl}_{3}\right) \delta 7.56-7.54(\mathrm{~m}, 2 \mathrm{H}), 7.42-7.39$ $(\mathrm{m}, 3 \mathrm{H}), 7.34-7.28(\mathrm{~m}, 2 \mathrm{H}), 7.06(\mathrm{~d}, J=8.4 \mathrm{~Hz}, 1 \mathrm{H}), 6.76(\mathrm{~d}, J=$ $8.4 \mathrm{~Hz}, 1 \mathrm{H}), 6.66$ (d, $J=8.0 \mathrm{~Hz}, 1 \mathrm{H}), 3.97-3.88(\mathrm{~m}, 2 \mathrm{H}), 3.84(\mathrm{~s}$, $6 \mathrm{H}), 3.14-2.99(\mathrm{~m}, 2 \mathrm{H}), 2.48-2.41(\mathrm{~m}, 1 \mathrm{H}), 2.37$ (dd, $J=7.2,4.8 \mathrm{~Hz}$, 1H), 2.23-2.16 (m, 1H), 1.22-0.95 (m, 2H). ${ }^{13} \mathrm{C}$ NMR (101 MHz, $\left.\mathrm{CDCl}_{3}\right) \delta 153.0,146.9,145.7,144.5,141.6,139.3,130.1,128.7$, 128.4, 127.1, 126.8, 125.6, 125.3, 123.1, 118.7, 110.4, 60.6, 56.1, 51.1, 44.2, 33.4, 30.9, 28.6, 21.9. HRMS (ESI): calcd for $\mathrm{C}_{26} \mathrm{H}_{27} \mathrm{ClNO}_{2}[\mathrm{M}+\mathrm{H}]^{+}$, 420.1725; found 420.1685.

(2R)- $N$-(5-Fluoro-2-methoxybenzyl)-5'-(4-fluorophenyl)-2', $3^{\prime}$ dihydrospiro[cyclopropane-1, $\mathbf{1}^{\prime}$-inden]-2-amine (32a). This compound was obtained from 28a and 5-fluoro-2methoxybenzaldehyde according to the methodology described for 13a. Yellow oil; yield 54\%. ${ }^{1} \mathrm{H}$ NMR (400 MHz, $\left.\mathrm{CDCl}_{3}\right) \delta 7.52-7.47(\mathrm{~m}, 2 \mathrm{H}), 7.36(\mathrm{~s}, 1 \mathrm{H}), 7.28-7.24(\mathrm{~m}, 1 \mathrm{H})$, $7.12-7.06(\mathrm{~m}, 2 \mathrm{H}), 7.02(\mathrm{dd}, J=8.8,3.2 \mathrm{~Hz}, 1 \mathrm{H}), 6.93-6.88(\mathrm{~m}$, $1 \mathrm{H}), 6.74(\mathrm{dd}, J=8.8,4.4 \mathrm{~Hz}, 1 \mathrm{H}), 6.65(\mathrm{~d}, J=7.6 \mathrm{~Hz}, 1 \mathrm{H}), 3.91-$ $3.76(\mathrm{~m}, 2 \mathrm{H}), 3.73(\mathrm{~s}, 3 \mathrm{H}), 3.13-2.98(\mathrm{~m}, 2 \mathrm{H}), 2.61(\mathrm{~s}, 1 \mathrm{H}), 2.48-$ $2.41(\mathrm{~m}, 1 \mathrm{H}), 2.36(\mathrm{dd}, J=7.2,4.8 \mathrm{~Hz}, 1 \mathrm{H}), 2.23-2.16(\mathrm{~m}, 1 \mathrm{H})$, 1.22-0.97 (m, 2H). ${ }^{13} \mathrm{C} \mathrm{NMR}\left(101 \mathrm{MHz}, \mathrm{CDCl}_{3}\right) \delta 162.2\left(\mathrm{~d}, J_{\mathrm{C}-\mathrm{F}}=\right.$ $246.6 \mathrm{~Hz}), 156.9$ (d, $\left.J_{\mathrm{C}-\mathrm{F}}=239.5 \mathrm{~Hz}\right), 153.7\left(\mathrm{~d}, J_{\mathrm{C}-\mathrm{F}}=2.0 \mathrm{~Hz}\right)$, 147.0, 144.6, 138.3, $137.7\left(\mathrm{~d}, J_{\mathrm{C}-\mathrm{F}}=3.2 \mathrm{~Hz}\right), 129.4\left(\mathrm{~d}, J_{\mathrm{C}-\mathrm{F}}=7.4\right.$ $\mathrm{Hz}), 128.5\left(\mathrm{~d}, J_{\mathrm{C}-\mathrm{F}}=8.0 \mathrm{~Hz}\right), 125.4,123.0,118.8,116.8\left(\mathrm{~d}, J_{\mathrm{C}-\mathrm{F}}=\right.$ $23.2 \mathrm{~Hz}), 115.5\left(\mathrm{~d}, J_{\mathrm{C}-\mathrm{F}}=21.4 \mathrm{~Hz}\right), 114.0\left(\mathrm{~d}, J_{\mathrm{C}-\mathrm{F}}=22.8 \mathrm{~Hz}\right)$, $110.9\left(\mathrm{~d}, J_{\mathrm{C}-\mathrm{F}}=8.1 \mathrm{~Hz}\right), 55.7,48.6,44.4,33.3,30.9,28.5,21.8$. HRMS (ESI): calcd for $\mathrm{C}_{25} \mathrm{H}_{24} \mathrm{~F}_{2} \mathrm{NO}[\mathrm{M}+\mathrm{H}]^{+}, 392.1820$; found 392.1801 .

\section{LSD1 and LSD2 inhibition assay}

Recombinant human LSD1 (172-852 aa) and full-length LSD2 were purchased from Sino Biological Inc. and Active Motif. LSD1 or LSD2 enzyme inhibition assay was performed with Lance Ultra LSD1 Histone H3-Lysine 4 Demethylase Assay kit (Perkin Elmer) according to the manufacturer's protocol. Briefly, LSD1/2 assay components were diluted in Tris buffer (50 mM Tris-HCl, 50 mM NaCl, 0.01\% Tween-20, 1 mM DTT, 10 $\mu \mathrm{M}$ FAD, $10 \%$ glycerol, $\mathrm{pH} 9.0$ ), and cultured for 1 hour at room temperature, which contained $4 \mu \mathrm{L}$ enzyme solution $(4 \mathrm{nM}$ LSD1 or $172 \mathrm{nM}$ LSD2), $4 \mu \mathrm{L}$ substrate solution $(2.5 \mu \mathrm{M}$ BioH3K4me2(1-24aa)), and $2 \mu \mathrm{L}$ inhibitor in 384-well microplate. And then, $5 \mu \mathrm{L}$ detection mix containing Eu-labeled H3K4me0 antibody and ULight-Streptavidin were added, and fluorescence intensity were measured with Envision (PerkinElmer) in TRFRET mode (excitation at 320 \& emission at $665 \mathrm{~nm}$ ). The test was carried out in triplicate. And the $\mathrm{IC}_{50}$ data was calculated using the software GraphPad Prism 5, and chosen the equation "sigmoidal dose-response (variable slope)" for curve fitting. 


\section{MAO-A and MAO-B inhibition assay}

MAO-A and MAO-B enzymes were purchased from SigmaAldrich and the inhibition assay was tested with Promega MAO-Glo ${ }^{\mathrm{TM}}$ Assay kit according to the manufacturer's protocol. The luminescent signals were detected using Envision (PerkinElmer). The test was carried out in triplicate. And the $\mathrm{IC}_{50}$ data was calculated using the software GraphPad Prism 5, and chosen the equation "sigmoidal dose-response (variable slope)" for curve fitting.

\section{Conflicts of interest}

There are no conflicts of interest to declare.

\section{Acknowledgements}

This work was supported by This work was supported by the Natural Science Foundation of Shanghai (16DZ2280100) and Strategic Priority Research Program Grant of the Chinese Academy of Sciences (XDA12020313).

\section{Notes and references}

1 Y. Shi, F. Lan, C. Matson, P. Mulligan and J. R. Whetstine, Cell, 2004, 119, 941-953.

2 R. J. Klose and Y. Zhang, Nat. Rev. Mol. Cell Biol., 2007, 8, 307-318.

3 M. G. Lee, C. Wynder, N. Cooch and R. Shiekhattar, Nature, 2005, 437, 432-435.

4 E. Metzger, M. Wissmann, N. Yin, J. M. Muller and R. Schneider, Nature, 2005, 437, 436-439.

5 J. Huang, R. Sengupta and A. B. Espejo, Nature, 2007, 449, 105-108.

6 A. Karytinos, F. Forneris, A. Profumo, G. Ciossani, E. Battalioli, C. Binda and A. Mattevi, J. Biol. Chem., 2009, 284, 17775-17782.

7 D. N. Ciccone, H. Su, S. Hevi, F. Gay, H. Lei, J. Bajko, G. Xu, E. Li and T. Chen, Nature, 2009, 461, 415-418.

8 Y. Chen, Y. Yang, F. Wang, K. Wan, K. Yamane, Y. Zhang and M. Lei, Proc. Natl. Acad. Sci. U. S. A., 2006, 103, 13956-13961.

9 A. Yokoyama, S. Takezawa, R. Schule, H. Kitagawa and S. Kato, Mol. Cell. Biol., 2008, 28, 3995-4003.

10 T. Lv, D. Yuan, X. Miao, Y. Lv, P. Zhan, X. Shen and Y. Song, PLoS One, 2012, 7, e35065.

11 M. Wissmann, N. Yin, J. M. Muller, R. Schneider and E. Metzger, Nat. Cell Biol., 2007, 9, 347-353.

12 S. Hayami, J. D. Kelly, H. S. Cho, M. Yoshimatsu, M. Unoki, T. Tsunoda, H. I. Field, D. E. Neal, H. Yamaue, B. A. J. Ponder, Y. Nakamura and R. Hamamoto, Int. J. Cancer, 2011, 128, 574-586.
13 Y. Wang, H. Zhang, Y. Chen, Y. Sun, F. Yang, W. Yu, J. Liang, L. Sun, X. Yang, L. Shi, R. Li, Y. Li, Y. Zhang, Q. Li, X. Yi and Y. Shang, Cell, 2009, 138, 660-672.

14 J. Ding, Z. M. Zhang, Y. Xia, G. Q. Liao, Y. Pan, S. Liu, Y. Zhang and Z. S. Yan, Br. J. Cancer, 2013, 109, 994-1003.

15 W. J. Harris, X. Huang, J. T. Lynch, G. J. Spencer, J. R. Hitchin, Y. Li, F. Ciceri, G. J. Blaser, B. F. Greystoke, A. M. Jordan, C. J. Miller, D. J. Ogilvie and T. C. P. Somervaille, Cancer Cell, 2012, 21, 473-487.

16 Y. Huang, T. M. Stewart, Y. Wu, S. B. Baylin, L. J. Marton, B. Perkens, R. J. Jones and P. M. Woster, Clin. Cancer Res., 2009, 15, 7217-7228.

17 A. Scoumanne and X. Chen, J. Biol. Chem., 2007, 282, 1547115475.

18 D. M. Schmidt and D. G. McCafferty, Biochemistry, 2007, 46, 4408-4416.

19 M. G. Lee, C. Wynder, D. M. Schmidt, D. G. McCafferty and R. Shiekhattar, Chem. Biol., 2006, 13, 563-567.

20 Y. C. Zheng, J. Ma, Z. Wang, J. Li, B. Jiang, W. Zhou, X. Shi, X. Wang and W. Zhao, Med. Res. Rev., 2015, 35, 1032-1071.

21 R. Neelamegam, E. L. Ricq, M. Malvaez, D. Patnaik, S. Norton, S. M. Carlin, L. T. Hill, M. A. Wood, S. J. Haggarty and J. M. Hooker, ACS Chem. Neurosci., 2012, 3, 120-128.

22 I. R. Kumarasinghe and P. M. Woster, ACS Med. Chem. Lett., 2014, 5, 29-33.

23 D. P. Mould, A. E. McGonagle, D. H. Wiseman, E. L. Williams and A. M. Jordan, Med. Res. Rev., 2015, 35, 586-618.

24 D. Rotili and A. Mai, Genes Cancer, 2011, 2, 663-679.

25 C. J. Kutz, S. L. Holshouser, E. A. Marrow and P. M. Woster, MedChemComm, 2014, 5, 1863-1870.

26 L. Y. Ma, Y. C. Zheng, S. Q. Wang, B. Wang, Z. R. Wang, L. P. Pang, M. Zhang, J. W. Wang, L. Ding, J. Li, C. Wang, B. Hu, Y. Liu, X. Zhang, J. Wang, Z. Wang, W. Zhao and H. Liu, J. Med. Chem., 2015, 58, 1705-1716.

27 F. Wu, C. Zhou, Y. Yao, L. Wei, Z. Feng, L. Deng and Y. Song, J. Med. Chem., 2016, 59, 253-263.

28 T. Maes, E. Carceller, J. Salas, A. Ortega and C. Buesa, Curr. Opin. Pharmacol., 2015, 23, 52-60.

29 X. Fu, P. Zhang and B. Yu, Future Med. Chem., 2017, 9, 12271242.

30 Y. C. Zheng, B. Yu, Z. S. Chen, Y. Liu and H. M. Liu, Epigenomics, 2016, 8, 651-666.

31 B. K. Albrecht, J. E. Audia and A. Cote, et al., WO2016123387A1, 2016, pp. 136.

32 M. Varasi, R. Amici, F. Thaler, C. Mercurio, P. Vianello and M. Pasi, WO2017109061A1, 2017, pp. 112.

33 Y. Zheng, C. M. Tice and S. B. Singh, Bioorg. Med. Chem. Lett., 2014, 24, 3673-3682. 